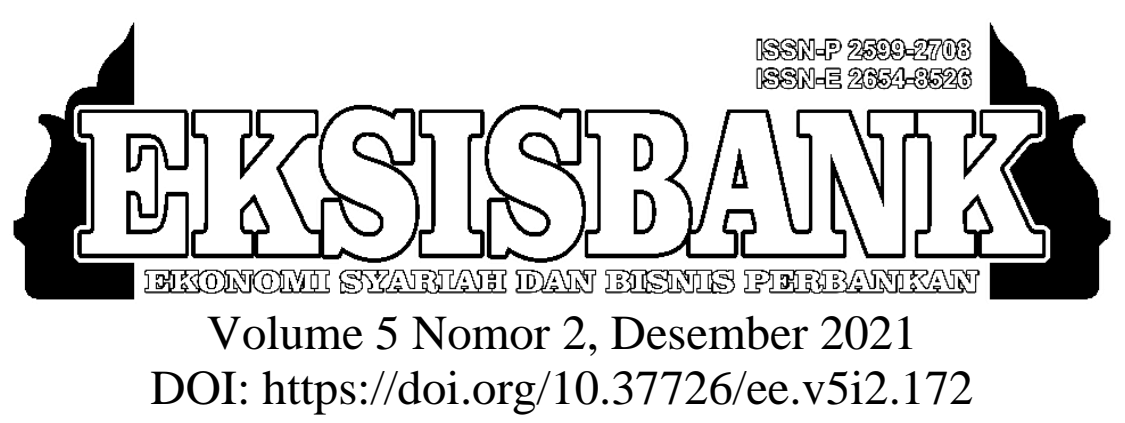

\title{
Pengaruh Kualitas Produk dan Promosi Terhadap Keputusan Nasabah Memilih Tabungan Amanah Di BMT Purwakarta Amanah Sejahtera
}

\author{
Wiwin Winanti ${ }^{1}$, Saepul Bahri ${ }^{2}$, Ayi Nurbaeti ${ }^{3}$, Diana Novita ${ }^{4}$ \\ ${ }^{1,2,3,4}$ Sekolah Tinggi Ilmu Ekonomi Syariah (STIES) Indonesia Purwakarta \\ ${ }^{1}$ wiwinwinanti079@gmail.com \\ 22saepulbahri@sties-purwakarta.ac.id \\ 3 ayinurbaeti@sties-purwakarta.ac.id \\ 4diananovita670@gmail.com
}

\begin{abstract}
ABSTRAK
Latar Belakang penelitian yang dilakukan di BMT Purwakarta Amanah Sejahtera, dimana Tabungan Amanah setiap tahunnya menurun. Hal ini kontraduktif dengan situasi masyarakat Purwakarta yang mayoritas penduduknya beragama islam. Merupakan potensi sebagai tempat tumbuhnya kegiatan ekonomi yang berbasis syariah. Tujuan penelitian ini adalah untuk mengetahui pengaruh Kualitas Produk terhadap keputusan nasabah memilih Tabungan Amanah, Untuk mengetahui pengaruh Promosi terhadap keputusan nasabah memilih Tabungan Amanah, Untuk mengetahui Kualitas Produk dan Promosi terhadap keputusan nasabah memilih Tabungan Amanah. Metode penelitian yang digunakan adalah metode kuantitatif, yaitu metode yang menggunakan angka-angka di setiap hasilnya dan diuji menggunakan aplikasi SPSS. Populasi dalam penelitian ini adalah 52 orang. Teknik analisis data yang digunakan dalam penelitian ini adalah validitas data, relibilitas data, untuk uji asumsi klasik menggunakan uji normalitas,uji multikolinearitas,uji heteroskedastis, sedangkan uji hipotesis menggunakan uji determinasi, uji parsial(uji t),regresi linier berganda,dan uji simultan (uji f). Hasil penelitian menunjukan bahwa variabel kualitas produk tidak berpengaruh terhadap keputusan nasabah tabungan amanah di BMT PAS dengan nilai thitung sebesar -0,309 lebih kecil dari ttabel sebesar 2,000. promosi secara parsial (uji t) tidak berpengaruh terhadap keputusan nasabah dengan thitung sebesar 1,753 lebih kecil dari ttabel sebesar 2,000. berdasarkan uji simultan (uji f) Kualitas produk dan promosi tidak berpengaruh terhadap keputusan nasabah dengan nila siginifikasi sebesar 0,194 lebih besar dari 0,05. Kesimpulannya hipotesis secara keseluruhan H0 diterima dan Ha ditolak.
\end{abstract}

Kata Kunci : Kualitas Produk, Promosi, Keputusan Nasabah 


\section{ABSTRACT}

The background of the research conducted at BMT Purwakarta Amanah Sejahtera, where the Amanah Savings decreased every year. This is contradictory to the situation of the Purwakarta people, where the majority of the population is Muslim. Is a potential place for the growth of sharia-based economic activities. To determine the effect of Product Quality on customer decisions to choose Amanah Savings, To determine the effect of Promotion on customer decisions to choose Amanah Savings, To determine Product Quality and Promotions on customer decisions to choose Amanah Savings. The theory presented by the author in the theoretical basis is the theory of Philip Kotler and Fandy Tjiptono for marketing theory, product quality, promotion and customer decisions. The research method used is a quantitative method, a method that uses numbers in each result and is tested using the SPSS application. The population in this study were 52 people. The data analysis techniques used in this study were data validity, data reliability, for the classical assumption test using normality test, multicollinearity test, heteroscedastic test, while hypothesis testing used determination test, partial test ( $t$ test), multiple linear regression, and simultaneous test. (f test). The results showed that the variable product quality had no effect on customer decisions of amanah savings at BMT PAS with a tcount of -0.309 , smaller than the t table of 2,000. promotion partially ( $t$ test) has no effect on customer decisions with $t$ count of 1.753 smaller than $t$ table of 2,000. based on the simultaneous test (f test). Product quality and promotion have no effect on customer decisions with a siginification value of 0.194 greater than 0.05. The conclusion is that the overall hypothesis $\mathrm{HO}$ is accepted and $\mathrm{Ha}$ is rejected.

Keywords: Product Quality, Promotion, Customer Decision

\section{PENDAhULUAN}

Lembaga keuangan syari'ah nampak mulai tumbuh di Indonesia, dimana lembaga tersebut seperti bank umum syari'ah, BPRS Syari'ah dan Baitul Maal Wat Tamwil telah mengelolah berjuta bahkan bermilyaran rupiah dana masyarakat sesuai dengan prinsip syari'ah (Soemitra 2008). Pada hakikatnya konsep BMT sudah ada di Indonesia sejak tahun 1992 yang dipelopori oleh Aries Mufti yang mendirikan BMT Bina Insan Kamil di Jakarta Pusat. Walau bagaimanapun, BMT secara resmi didirikan pada tahun 1995 setelah Bank Muamalat Indonesia dibentuk (Muhammad 2009).

BMT di Indonesia merupakan lembaga keuangan berbasis syari'ah yang berprospek tumbuh karena didukung oleh potensi sumber daya alam dan sumber daya manusia serta mayoritas penduduknya adalah beragama Islam (Gayo and Taufik 2012). Sebagai sebuah lembaga keuangan yang tengah berkembang, BMT tentunya tidak terlepas dari ketatnya persaingan antar BMT saja tetapi lembaga keuangan lainnya.

Pada tahun 2019 dari total sekitar 265 juta penduduk, $40 \%$ merupakan masyarakat kelas menengah dari $20 \%$ digolongkan sebagai kelas bawah, ditambah sebanyak kurang lebih 25,65 juta jiwa dikategorikan sebagai penduduk miskin atau 9,66 jumlah penduduk. Dengan pertumbuhan jumlah. BMT di Indonesia pada tahun 2019 bisa dibilang cukup pesat dimana saat ini sudah berdiri sekitar 4.500 unit, meskipun angka tersebut masih diragukan faktanya dilapangan (Kamila 2021; Kurniati and Guritno 2019).

Dikabupaten Purwakarta yang mayoritas penduduknya beragama Islam, merupakan potensi sebagai tempat tumbuh kembangnya kegiatan ekonomi yang berbasis syariah. Meskipun mayoritas penduduk Purwakarta

EKSISBANK (Ekonomi Syariah dan Bisnis Perbankan), Volume 5, Nomor 2, Desember 2021 
adalah beragama islam, tetapi pengembangan produk syariah berjalan lambat hal ini dikarenakan banyaknya lembaga keuangan konvesional. Sebagai sebuah Lembaga Keuangan Syariah pada awal berdirinya untuk bisa bermuamalah dalam bidang ekonomi yang sesuai dengan syariat islam juga harus bersaing dengan para pesaing untuk merebut nasabah.

Salah satu lembaga keuangan yang berbasis syariah yang ada di purwakarta adalah Baitul Maal Wat Tamwil Purwakarta Amanah Sejahtera, yang didirikan pada tanggal 29 September 2017. Sesuai namanya BMT Purwakarta Amanah Sejahtera (PAS) memiliki bidang usaha Baitul Mal yang besifat sosial atau nonprofit motive, di antaranya mengumpulkan dan menyalurkan zakat, infak, sedekah, dan wakaf. Sementara bidang usaha lainnya adalah Baitul Tamwil yang bersifat bisnis dan profit orieted yakni dengan penghimpunan dana dan menyalurkan dana (Aini, Habriyanto, and Putra 2021).

BMT Purwakarta Amanah Sejahtera juga menawarkan produk pengimpun dana (tabungan). Tabungan adalah simpanan yang penarikannya hanya dapat dilakukan menurut syarat tertentu yang disepakati, tetapi tidak dapat ditarik dengan cek, bilyet giro atau alat lainnya yang disamakannya dengan ini (Anshori 2018). Tujuan masyarakat menabung yaitu untuk berjaga-jaga jika terjadi sesuatu yang tidak diinginkan. Menabung adalah tindakan yang dianjurkan oleh islam karena dengan menabung berarti seorang muslim mempersiapkan diri untuk masa depannya.

Salah satu produk penghimpun dana yang ada di BMT Purwakarta Amanah Sejahtera yaitu Tabungan Amanah merupakan tabungan anggota dengan akad wadiah yad dhamanah yang berarti BMT PAS dapat memanfaatkan dana dan menyalurkan dana yang disimpan serta menjamin bahwa dana tersebut dapat ditarik setiap saat oleh anggota.

Tabungan Amanah ini merupakan untuk membantu memenuhi kebutuhan masyarakat yang ingin menabung. Tabungan ini didesain untuk memberikan kemudahan disertai pelayanan yang baik bagi kalangan mahasiswa serta masyarakat umum. Hal ini ditunjukan dengan jumlah nasabah BMT Purwakarta Amanah Sejahtera yang mengalami penurunan disetiap tahunnya.

Grafik 1.1

Jumlah Nasabah Tabungan Amanah di BMT Purwakarta Amanah Sejahtera (PAS)

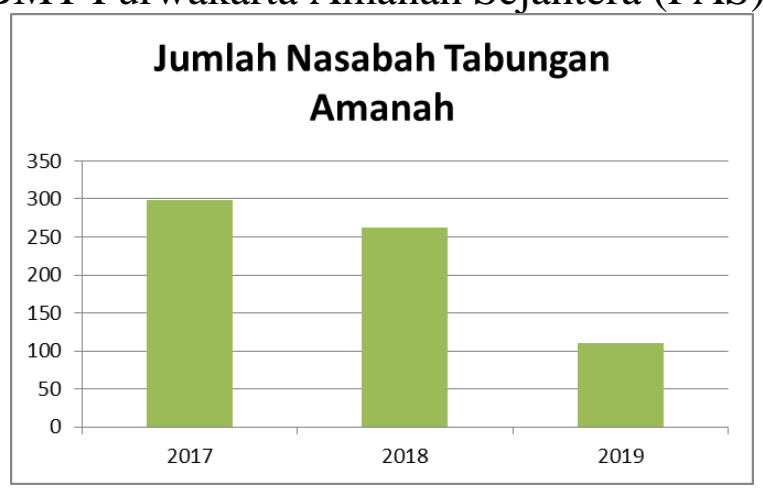

Sumber : BMT Purwakarta Amanah Sejahtera (PAS)

Perkembangan nasabah yang menggunakan tabungan amanah pada tahun 2017 sebanyak 298, pada tahun 2019 pengguna tabungan amanah sebanyak 262, dan pada tahun 2019 pengguna tabungan amanah sebanyak 110. Dari data tersebut ditunjukan bahwa jumlah nasabah yang menggunakan tabungan amanah mengalami penurunan di setiap tahunnya.

Beberapa faktor yang menyebabkan terjadinya penurunan, diantaranya dapat dilihat dari kualitas produk, dan promosi yang dilakukan oleh pihak BMT Purwakarta Amanah Sejahtera. Untuk menentukan kualitas produk dan promosi yang baik, perbankan terlebih dahulu harus memahami calon nasabahnya sebagai pengguna jasa yang ditawarkan, 
Nasabah akan memperhatikan faktorfaktor tertentu sebelum memutuskan untuk memilih produk tabungan yang akan digunakan. BMT PAS juga dituntut untuk selalu mengikuti keinginan dan kebutuhan nasabah. Produk yang ditawarkan haruslah suatu produk yang benar-benar teruji dengan baik mengenai kualitasnya, karena bagi konsumen yang diutamakan adalah kualitas produk dari produk itu sendiri. Kualitas yang terjadi pada produk yang dihasilkan juga harus memenuhi nilai-nlai kebutuhan di dalamnya. Suatu produk dikatakan berkualitas jika produk tersebut sudah memenuhi keinginan konsumen bahkan melebihi apa yang konsumen harapkan.

Nasabah membeli jasa untuk memenuhi kebutuhannya dan nasabah akan memberikan nilai dalam proporsi terhadap kemampuan layanan untuk melakukan hal tersebut. Nilai yang diberikan nasabah yang berhubungan benefit atau keuntungan yang diterimanya. Kualitas produk didapatkan dengan cara menemukan keseluruhan harapan pelanggan, meningkatkan nilai produk atau pelayanan dalam rangka memenuhi harapan pelanggan tersebut. Kualitas memang menjadi faktor penentu keberhasilan saat ini, suatu perusahaan harus selalu memperhatikan kualitas produk yang ditawarkan kepada masyarakat jika ingin terus berkembangan. Perusahaan yang memiliki kualitas yang lebih baik akan memberikan customer value yang lebih baik. Dengan demikian perusahaan dapat mempertahankan nasabah serta menarik nasabah baru, yang pada akhirnya perusahaan tersebut mampu meningkatkan tingkat penjualan.

Dalam mensosialisasikan produk yang dimiliki seperti tabungan, BMT juga harus memberikan informasi kepada masyarakat melalui promosi. Promosi yang dapat dilakukan bank harus memberikan informasi yang tepat dimana komunikasi berperan penting, dalam hal ini promosi menjadi suatu yang berharga. Karena, komunikasi merupakan karakter yang penting dalam membangun hubungan. Dengan diadakan promosi maka masyarakat mengetahui apa saja yang diberikan oleh BMT Purwakarta Amanah Sejahtera (PAS) serta menambah minat masyarakat untuk menabung. Namun tindakan promosi oleh BMT Purwakarta Amanah Sejahtera juga bisa mengurangi niat masyarakat bila dilakukan dengan tujuan yang tidak tepat atau berlebihan oleh karena itu BMT Purwakarta Amanah Sejahtera (PAS) harus dapat memanfaatkan dengan benar media promosi seperti iklan media cetak atau elektronik, promosi langsung atau mengadakan event atau acara yang tersedia.

Promosi merupakan topik yang menarik untuk ditelusuri, sebab promosi merupakan bagian yang tak terpisahkan dari perbankan yang berfungsi sebagai sumber informasi bagi masyarakat serta menjadi salah satu pertimbangan dalam menempatkan dananya disuatu bank. Promosi merupakan suatu alat komunikasi perusahaan dengan nasabahnya. Selain sebagai alat komunikasi dengan nasabah, promosi juga bertujuan untuk menarik calon nasabah untuk menggunakan produk yang ditawarkan. Promosi merupakan sarana yang ampuh untuk menarik minat nasabah dari yang tidak suka menjadi suka sehingga berdampak pada meningkatnya jumlah nasabah (Romindo et al. 2019). Promosi yang dilakukan harus dikemas dengan menarik. Promosi yang menarik tersebut diharapkan dapat mempengaruhi masyarakat dalam mengambil keputusan. kegiatan promosi haruslah dilakukan secara terarah dan efisien sehingga memberikan pengaruh yang posotif terhadap meningkatnya penjual. Pada akhirnya bisa memperoleh nasabah baru dan mempertahankan nasabah lama. 
Kualitas produk dan promosi yang berbeda menjadi salah satu faktor yang mempengaruhi nasabah untuk memutuskan menjadi anggota pada lembaga keuangan yang diinginkan, Keputuskan sebagai pemilih suatu tindakan dua atau lebih pemilihan alternatif, Seorang konsumen yang hendak melakukan pilihan maka ia harus memiliki alternatif. Banyaknya macam lembaga keuangan syariah dan produk tabungan wadiah yang ditawarkan menjadikan banyak alternatif.

Berdasarkan uraian di atas maka tujuan penelitian ini adalah untuk mengetahui pengaruh Kualitas Produk terhadap keputusan nasabah memilih Tabungan Amanah, Untuk mengetahui pengaruh Promosi terhadap keputusan nasabah memilih Tabungan Amanah, Untuk mengetahui Kualitas Produk dan Promosi terhadap keputusan nasabah memilih Tabungan Amanah.

\section{A. Kajian Teori}

\section{Kualitas Produk}

\section{a.Pengertian Kualitas Produk}

Menurut Joseph M Juran dalam buku yang dikutip Fandy Tjiptono, mendefinisikan kualitas sebagai kesesuaian terhadap spesifikasi atau pemakaian.

Menurut Juran kualitas dapat dibangun dengan tahapan-tahapan tertentu yang jelas berbeda antara satu dengan yang lainnya, tergantung dengan produk yang akan dihasilkan. Permasalahan yang timbul dan mengganggu kualitas harus secepatnya dihilangkan. Pengendalian kualitas dilakukan agar kepuasan pelanggan menjadi prioritas yang utama (Tjiptono 2011).

Menurut Kolter, produk adalah segala sesuatu yang ditawarkan ke pasar untuk mendapatkan perhatian, permintaan, pemakaian, atau konsumsi yang dapat memenuhi kebutuhan dan keinginan konsumen (Kotler and Armstrong 2008).
Menurut Kolter kualitas produk adalah karakteristik produk dan jasa yang bergantung pada kemampuannya untuk memuaskan kebutuhan pelanggan yang dinyatakan atau di implementasikan(Kotler and Amstrong 2012). Kualitas berkaitan erat dengan kepuasan pelanggan, kualitas memberikan dorongan khusus bagi para pelanggan untuk menjalin ikatan relasi saling menguntungkan dengan perusahaan dalam jangka panjang (Kotler and Amstrong 2012).

Jadi dari definisi diatas dapat diambil kesimpulan bahwa kualitas produk merupakan keunggulan suatu produk dalam melaksanakan fungsinya, termasuk keawetannya, keandalan, ketepatan, kemudahan penggunaan dan perbaikan. Konsumen pada era sekarang lebih cerdas, mereka akan mengalihkan produk yang telah dikonsumsinya jika ada tawaran produk lain dengan harga yang relative sama tetapi memberikan kualitas yang lebih.

Produk yang dihasilkan oleh dunia usaha umumnya terbentuk dua macam, yaitu produk yang terwujud dan produk yang tidak terwujud. Masing-masing produk dapat dikatakan terwujud atau tidak terwujud memiliki karakteristik atau ciri-ciri tertentu. Produk yang terwujud berupa barang yang dapat dilihat, dipegang, dan dirasa sekarang langsung sebelum dibeli, sedangkan produk yang tidak terwujud berupa jasa dimana tidak dapat dilihat atau dirasa sebelum dibeli.

Dalam dunia perbankan dimana produk yang dihasilkan berbentuk jasa, maka ciri-ciri produk yang berbentuk jasa adalah sebagai berikut (Kasmir 2018) :

1)Tidak berwujud, artinya tidak dapat dirasakan atau dinikmati sebelum jasa tersebut dibeli atau dikonsumsi. Oleh karena itu, jasa tidak memiliki wujud tertentu sehingga harus dibeli dahulu.

2)Tidak terpisahkan, artinya antara si pembeli jasa dengan si penjual jasa saling

EKSISBANK (Ekonomi Syariah dan Bisnis Perbankan), Volume 5, Nomor 2, Desember 2021 
berkaitan satu sama lainnya, tidak dapat dititipkan melalui orang lain.

3)Beraneka ragam, artinya jasa dapat diperjual belikan dalam berbagai bentuk dan wahana seperti tempat, waktu, atau sifat.

4)Tidak tahan lama, artinya jasa tidak bisa disimpan begitu saja, jika dibeli maka harus segera dikonsumsi.

\section{b.Dimensi Kualitas Produk}

Menurut Mullins, Orville. Larreche, dan Boyd apabila perusahaan ingin mempertahankan keunggulan kompetetifnya dalam pasar, perusahaan harus mengerti aspek dimensi apa saja yang digunakan oleh konsumen untuk membedakan produk yang dijual perusahaan tersebut dengan produk pesaing, indicator dari kualitas produk terdiri dari :

1) Performance (Kinerja)

Berhubungan dengan karakteristik operasi dasar dari sebuah produk.

2) Durability (Daya Tahan)

Yang berarti berapa lama atau umur produk yang bersangkutan bertahan sebelum produk tersebut harus diganti. Semakin besar frekuensi pemakaian konsumen terhadap produk maka semakin besar pula daya tahan produk.

3) Comformance To Specifications (Kesesuaian Dengan Spesifikasi)

Yaitu sejauh mana karakteristik operasi dasar dari sebuah produk memenuhi spesifikasi tertentu dari konsumen atau tidak ditemukannya cacat pada produk.

4) Features (Fitur)

Adalah produk yang dirancang untuk menyempurnakan fungsi produk atau menamabah ketertarikan terhadap produk.

5) Reliability (relibilitas)

Adalah probabilitas bahwa produk akan bekerja dengan memuaskan atau tidak dalam periode waktu tertentu. Semakin kecil kemungkinan terjadinya kerusakan maka produk tersebut dapat diandalkan.

6) Aesthetics (Estetika)

Berhubungan dengan bagaimana penampilan produk bisa dilihat dari tampak, rasa, bau, dan bentuk dari produk.

7) Perceived Quality (Kesan Kualitas)

Sering dibilang merupakan hasil dari penggunaan pengukuran yang dilakukan secara tidak langsung karena terdapat kemungkinan bahwa konsumen tidak mengerti atau kekurangan informasi atas produk yang bersangkutan.

\section{c. Kualitas Produk Dalam Pandangan Islam}

Kualitas mempunyai arti sangat penting dalam keputusan pembelian konsumen. Apabila kualitas produk yang dihasilkan baik maka konsumen akan cenderung melakukan pembelian ulang sedangkan, bila kualitas produk yang tidak baik maka konsumen tidak akan melakukan pembelian ulang. Kualitas produk sebagai keseluruhan gabungan karakteristik produk dari pemasaran, rekayasa pembikinan dan pemeliharaan yang membuat produk yang digunakan memenuhi harapan pelanggan. Jadi kualitas produk adaalah sejumlah atribut atau sifat-sifat yang dideskripsikan di dalam produk (barang dan jasa) dan digunakan untuk memenuhi harapan-harapan pelanggan. Sebagaimana firman Allah SWT QS. An-Naml ayat 88 sebagai berikut :

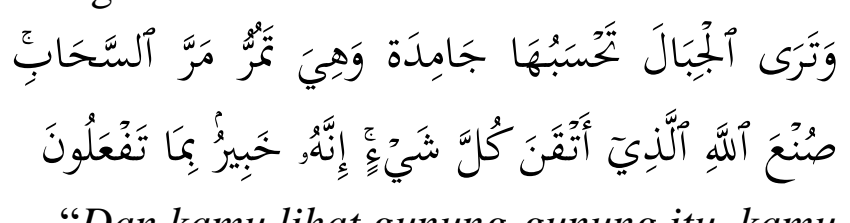

"Dan kamu lihat gunung-gunung itu, kamu sangka dia tetap di tempatnya, padahal ia berjalan sebagai jalannya awan. (Begitulah) perbuatan Allah yang membuat

EKSISBANK (Ekonomi Syariah dan Bisnis Perbankan), Volume 5, Nomor 2, Desember 2021 
dengan kokoh tiap-tiap sesuatu, sesungguhnya Allah Maha mengetahui apa yang kamu kerjakan" (Subarkah et al. 2012).

Ayat ini menjelaskan bahwa dalam memproduksi suatu barang harus diselesaikan dengan kualitas yang sempurna dan sebaikbaiknya karena Allah sendiri sudah menciptakan semua yang ada dilangit dan di bumi dengan kualitas yang sangat sempurna. Bila suatu produk telah dapat dikatakan sebagai produk yang memiliki kualitas yang baik, produk tersebut juga harus diselesaikan dengan kualitas yang sempurna.

\section{Promosi}

Menurut Kotler promosi adalah bagian dan proses strategi pemasaran sebagai cara untuk berkomunikasi dengan pasar dengan menggunakan komposisi bauran promosi “. romotional mix”. Menurut Michael Ray, promosi adalah koordinasi dari seluruh upaya yang dimulai pihak menjual untuk membangun berbagai saluran informasi dan persuasi untuk menjual barang dan jasa atau memperkenalkan suatu gagasan (Morrisan 2015).

Kegiatan promosi adalah kegiatan yang paling penting dan sangat berpengaruh besar terhadap kemajuan sebuah lembaga, karena sebagus apapun jika tanpa promosi, masyarakat tidak akan mengetahui keunggulan dan manfaat suatu produk. Indikator promosi menurut Philip Kotler adalah sebagai berikut:

1) Penjualan Promosi.

2) Iklan.

3) Organisasi Penjualan.

4) Hubungan Masyarakat.

5) Pemasaran Langsung

\section{a.Unsur-Unsur Promosi}

Bauran promosi mencangkup empat elemen, secara tradisional. Yaitu: iklan
(advertising),Promosi penjualan (sales promotion), publikasi (humas), dan personal selling. Namun ada penambahan dua terakhir dalam elemen promotional mix, yaitu direct marketing dan interacktive media.

Advertising atau periklanan merupakan salah satu bentuk kegiatan promosi yang sering dilakukan lembaga! perusahaan melalui komunikasi non individu dengan sejumlah biaya seperti iklan melalui media masa, perusahaan iklan, lembaga non laba, media sosial. Periklanan dilakukan untuk menjangkau segmen pasar yang tidak telj angkau oleh personal selling.

Adapun Sifat dari advertising adalah sebagai Presentasi umum, artinya advertising yang bersifat umum tersebut memberikan semacam keabsahan pada produk dan menyarankan tawaran yang terstandardisasi. Tersebar luas, artinya advertising adalah media berdaya sebar luas yang memungkinkan penjual mengulang pesan berkali-kali. Advertising juga memungkinkan pembeli menerima dan membandingkan dengan berbagai pesaing. Ekspresi yang kuat, artinya periklanan memberikan peluang untuk mendramatisasi bank dan produknya melalui penggunaan cetakan, suara, warna yang penuh seni. Tidak bersifat pribadi, artinya audience sasaran tidak merasa wajib memberikan perhatian dan menanggapi advertising. Iklan hanya mampu melakukan monolog, bukan dialog, dengan audience (Susanto and Umam 2013).

Tugas advertising adalah memberi ajakan kepada nasabah/konsumen untuk mengenal dan menggunkan produk, sedangkan sales promotion mengajak agar bergabung menjadi nasabah sekarang. Berbagai insentif jangka pendek untuk mendorong keinginan mencoba atau membeli suatu produk atau jasa. Tujuan digunakan sales promotion, menarik nasabah baru, memberikan hadiah pada nasabah baru/lama, mengajak nasabah untuk 
menggunakan produk lain sesuai dengan kebutuhan dan meningkatkan loyalitas.

Berbagai cara sales promotion yang ditawarkan yaitu: memberikan cashback kepada nasabah, memberikan potongan cicilan dan memberikan hadiah langsung jika nasabah melunasi cicilan tepat waktu pada saat melakukan pembiayaan.

Sifat dari sales promotion adalah sebagai Komunikasi, artinya promosi penjualan menarik perhatian dan biasanya memberikan informasi yang dapat mengarahkan nasabah ke produk yang bersangkutan. Insentif, artinya promosi penjualan menggabungkan sejumlah kebebasan, dorongan, atau kontribusi yang memberi nilai bagi nasabah. Ajakan, artinya promosi penjualan merupakan ajakan untuk melakukan transaksi pembelian sekarang.

Public Relation Menurut Philip Kotler, public relation ialah "publicity" yang didefmisikan sebagai: activities to promote a company or its product by planting news about it in media, not paid for by the sponsor. Berbagai program untuk mempromosikan dan atau melindungi citra bank atau masingmasing produknya.

Sifat dari public relation adalah sebagai Kredibilitas yang tinggi, artinya cerita dan gambar mengenai beritanya lebih otentik dan dipercaya oleh pembaca dibandingkan dengan iklan. Kemampuan menangkap pembeli yang tidak dibidik sebelumnya, artinya humas dapat menjangkau banyak calon pembeli yang cenderung menghindari wariniaga dan iklan. Dramatisasi, artinya humas memiliki kemampuan untuk mendramatisasi suatu bank atau produk (Soemitra 2008).

Personal Selling adalah kegiatan promosi yang dilakukan antar individu yang sering bertemu muka yang ditunjukan untuk menciptakan, memperbaiki, menguasai atau mempertahankan hubungan pertukaran yang saling menguntungkan kedua belah pihak (Susanto and Umam 2013).

Sifat dari personal selling adalah sebagai Konfrontasi personal, artinya mencangkup hubungan yang hidup, langsung dan interaktif antara dua orang atau lebih. Masing-masing pihak dapat mengobservasi reaksi dari pihak lain dengan lebih dekat. Mempererat, artinya memungkinkan timbulnya berbagai jenis hubungan, mulai hubungan penjualan sampai hubungan persahabatan. Tanggapan, artinya membuat pembeli merasa berkewajiban untuk mendengarkan pembicaraan wiraniaga (Susanto and Umam 2013).

Direct marketing adalah penggunaan surat, telepon, faksimili, email, dan alat-alat penghubung nonpersonal lainnya untuk berkomunikasi secara langsung dengan atau mendapatkan tanggapan langsung dari pelanggan dan calon pelanggan.

Sifat dari direct marketing adalah sebagai Nonpublik, artinya pesan ditunjukan kepada orang tertentu. Disesuaikan, artinya pesan dapat menarik orang yang dituju. Terbaru, artinya pesan dapat disiapkan dengan cepat. Interaktif, artinya pesan dapat diubah tergantung dari tanggapan orang tersebut (Susanto and Umam 2013).

Interactive media adalah kegiatan interaksi dengan konsumen atau nasabah dengan menggunakan media perantara untuk berkomunikasi.

\section{b.Bauran Promosi}

Bauran promosi terdiri dari empat unsur, yakni: Periklanan (advertising), personal selling, publisitas (publicity), promosi penjualan.

1)Periklanan (advertising)

Iklan adalah sarana promosi yang digunakan oleh bank guna menginformasikan, menarik, dan mempengarauhi calon nasabahnya

2)Promosi penjualan (sales promotion) 
Selain promosi lewat iklan, promosi lainnya dapat dilakukan melalui promosi penjualan atau sale promotion. Tujuan promosi penjualan adalah untuk meningkatkan penjualan atau untuk meningkatkan jumlah nasabah. Promosi penjualan dilakukan untuk menarik nasabah untuk segera membeli setiap produk atau jasa yang di tawarkan. Tentu saja agar nasabah tertarik untuk membeli, maka dapat dibuatkan promosi penjualan, yang semenarik mungkin.

3)Publisitas (publicity)

Promosi yang ketiga adalah publisitas. Publisitas merupakan kegiatan promosi untuk memancing nasabah melalui kegitan seperti pameran, bakti sosial serta lainya. Kegiatan publisitas dapat meningkatkan pamor di bank di mata para nasabahnya. Oleh karena itu, publisitas dapat diperbanyak lagi.

4)Penjualan pribadi (Personal Selling)

Kegitan promosi yang keempat adalah penjualn pribadi atau Personal Selling. Dalam dunia perbankan penjualan pribadi secra umum dilakukan oleh seluruh pegawai bank, mulai dari Cleaning Service, satpam sampai pejabat bank. Secra khusus Personal Sealling dilakukan oleh petugas Customer Service atau Service Assistensi (Kasmir 2018).

\section{c. Tujuan Promosi}

1) Memperkenalkan persahaan pada masyarakat luas dalam sebagian basil riset menunjukan bahwa sebagian besar konsumen belum mengetahui keberadaan perusahaan.

2) Mendidik para pengguna atau konsumen agar mereka lebih efektif dan mengerti dalam memanfaatkan produk-produk perusahaan/lembaga jika hasil riset menunjukan sebagian besar khalayak pengguna atau konsumen belum memahami manfaat produk yang dihasilkan perusahaan.

3) Mengubah citra perusahaan dimata masyarakat karena adanya produk atau kegiatan baru jika hasil riset menunjukan khalayak belum mengetahui bahwa ada produk baru atau kegiatan baru (Morrisan 2015).

\section{Keputusan Nasabah}

Keputusan dalam arti umum adalah " $a$ decision is the selection of an option from two or more alternative choices." Yaitu suatu keputusan seseorang dimana memilih salah satu dari beberapa alternatif pilihan yang ada. Definisi keputusan pembelian menurut Nugroho, adalah proses pengintegrasian yang mengkombinasi sikap pengetahuan untuk mengevaluasi dua atau lebih perilaku alternatif, dan memilih salah satu diantaranya (Fakhrurradhi 2021).

Keputusan adalah suatu pengakhiran dari pada proses pemikiran tenatang suatu masalah atau problema untuk menjawab pertanyaan apa yang harus diperbuat guna mengatasi masalah tersebut. Dengan menjatuhkan pilihan pada suatu alternatif. Sedangkan pengambilan keputusan adalah proses memilih sejumlah alternative (Fahriana 2018). Secara harfiah pengambilan keputusan berarti memotong atau memutuskan secara praktis mencapai suatu kesimpulan (F. Sari 2018).

Dalam konteks perilaku konsumen, maka pengambilan keputusan konsumen (consumer decision marketing) menurut Wike yang dikutip Huriyati dapat didefinisikan sebagai aktivitas dimana seseorang melibatkan diri dalam proses menyeleksi, membeli dan mempergunakan barang dan jasa sehingga memuaskan kebutuhan dan hasratnya. Beberapa aktivitas melibatkan mental dan proses emosional, sebagai tambahan dari reaksi fisik (Ratih 2005). Sedangkan menurut 
Kotler keputusan pembelian adalah tindakan dari konsumen untuk mau membeli atau tidak terhadap produk (Kotler and Keller 2009).

Dari beberapa definisi diatas dapat disimpulkan bahwa pengambilan keputusan merupakan kemampuan menganalisis situasi dengan memperoleh informasi seakurat mungkin, menyeleksi membeli dan mempergunakan barang dan jasa untuk memuaskan kebutuhan. Sehingga dapat memilih diantara alternatif-alternatif yang ada.

Sedangkan Menurut Salusu keputusan nasabah adalah proses memilih suatu alternatif cara bertindak dengan metode yang efisien sesuai situasi.

Menurut Amirullah Keputusan nasabah adalah suatu proses penilaian dan pemilihan dari berbagai alternatif sesuai dengan kepentingan-kepentingan tertentu dengan menetapkan suatu pilihan yang dianggap paling menguntungkan (Salusu 2015).

Menurut Fandy Tjiptono dalam pengambilan keputusan nasabah mempunyai proses yang dapat dilihat dari tahap-tahap sebagai berikut (Tjiptono 2020) :

1) Identifikasi Masalah

Proses membeli atau mengkonsumsi di mulai dengan pengenalan masalah atau kebutuhan. Setiap konsumen memiliki masalah atau kebutuhan yang berbedabeda sehingga membuat hal tersebut dapat membedakan pengambilan keputusan pada setiap konsumen.

2) Pencarian Informasi

Setelah mengenal kebutuhan yang dihadapinya, konsumen akan mencari informasi lebih lanjut atau mungkin tidak, pencarian informasi lebih lanjut bisa berguna untuk konsumen yang mengetahui produk yang akan dipakai. Informasi bisa di dapat lewat media cetak ataupun online karena pada saat ini teknologi sudah semakin berkembang sehingga dapat memudahkan konsumen untuk mendapatkan informasi suatu produk yang sesuai kebutuhan.

3) Evaluasi Alternatif

Setelah melalui tahap pencarian informasi, pada tahap ini konsumen membandingkan merek dan produk yang mempertimbangkan mereka.

4) Pembelian dan Konsumsi

Tahap konsumsi dan pembelian ini adalah tahap akhir, dalam pengambilan keputusan konsumen membentuk pilihan mereka diantara merek yang tergabung dalam perangkat pilihan. Konsumen mungkin juga membentuk suatu pilihan untuk membeli dan cenderung membeli merek yang disesuaikan.

5) Evaluasi Purnabeli

Setelah memakai suatu produk atau jasa, konsumen akan mengalami beberapa tingkat kepuasan atau ketidak puasan. Tugas pemasar belum selesai setelah produk dibeli atau jasa digunakan oleh konsumen, namun akan berlangsung hingga priode waktu pasca pembelian.

\section{a.Faktor-Faktor Yang Mempengaruhi Keputusan Konsumen}

1) Perbedaan Individu

Perbedaan individu menggambarkan faktor-faktor karakteristik individu yang muncul dari dalam diri konsumen dan proses psikologis yang terjadi pada dirikonsumen yang sangat berpengaruh terhadap proses keputusan konsumen yaitu (Sumarwan 2011):

a)Kebutuhan Dan Motivasi

Motivasi muncul karena adanya kebutuhan yang dirasakan oleh konsumen Kebutuhan sendiri muncul karena konsumen merasakan ketidak nyamanan anatara seharusnya dirsakan dan sesunggunya dirasakan. Untuk memenuhi kebutuhannya, seseorang 
konsumen harus memiliki tujuan akan tindakannya. Tujuannya adalah suatu cara untuk memenuhi kebutuhannya Maslow mengemukakan lima kebutuhan manusia berdasarkan tingkat kepentingan mulai dari yang paling rendah, yaitu kebutuhan biologis, sampai paling tinggi yaitu kebutuhan psikogenik (Sumarwan 2011).

b)Kepribadian

Kepribadian adalah salah satu dari banyak faktor yang mempengaruhi pola konsumen seseorang. Perilaku mungkin berbeda antar orang yang memiliki kesamaan satu kepribadian, karena perilaku berinteraksi dengan situasi konsumen dan faktor lainnya (Firmansyah 2019). Perbedaan dalam kepribadian konsumen akan mempengaruhi perilakunya dalam memilih produk atau jasa, karena konsumen akan membeli barang yang sesuai dengan kepribadiannya (Wardana 2011).

c)Konsep diri

Adalah persepsi atau perasaan seseorang terhadap dirinya, Konsep diri seseorang menggambarkan bagaimana sikap orang tersebut terhadap dirinya. Konsep diri sangat terkait dengan karakter atau sifat-sifat dari kepribadian seseorang (Setiadi 2019).

d)Pengelolaan informasi dan persepsi konsumen

Pengelolaan informasi pada diri konsumen terjadi ketika salah satu pancaindra konsumen menrima input dalam bentuk stimulus. Stimulus bisa dalam bentuk produk. konsumen seringkali memutuskan pembelian suatu produk berdasarkan persepsinya terhadap produk tersebut (Sumarwan 2011).

e)Proses pembelajaran konsumen

Proses pembelajaran konsumen dapat diartikan sebagai ssebuah proses dimana seseorang memperoleh pengetahuan danpengalaman pembelian dan konsumsi yang akan di terapkan pada perilaku yang terkait pada masa yang akan datang. Konsumen tidak akan pernah berhenti belajar. Ia akan menerima informasi setiap saat dan dimanapun, karena ia akan selalu memperoleh pengetahuan baru dari membaca, melihat, mendengarkan, berpikir dan bahkan dari pengalamannya. Semua proses belajar ini akan mempengaruhi apa yang diputuskan, apa produk yang akan dibeli (Rumondang et al. 2020).

f) Pengetahuan konsumen

Pengetahuan konsumen adalah semua informasi yang dimiliki konsumen menegnai berbagai macam produk dan jasa, serta penegathuan lainnya yang terkait dengan produk dan jasa tersebut dan informasi yang berhubungan dengan fungsinya sebagai konsumen. Pengetahuan konsumen akan mempengaruhi keputusan konsumen (Muttalib 2018).

g)Sikap konsumen

Sikap konsumen adalah faktor yang penting yang akan mempengaruhi keputusan konsumen.

h)Pengaruh agama terhadap perilaku konsumen

Agama adalah salah satu karakteristik demografi yang sangat penting (Muchammadun et al. 2021).

2) Faktor lingkungan

a) Budaya

Segala nilai pemikiran dan symbol yang mempengaruhi perilaku, sikap, 
kepercayaan dan kebiasaan seseorang dan masyarakat. produk dan jasa memainkan peranan yang sangat penting dalam mempengaruhi budaya. Karena produk mampu membawa pesan makna budaya (Sumarwan 2011).

b) Karakteristik demografi, sosial,dan ekonomi konsumen

Beberapa karakteristik demografi yang sangat penting untuk memahami konsumen adalah usia, jenis kelamin, pekerjaan pendidikan, agama, suku bangsa, pendapatan, jenis keluarga.

c) Keluarga dan rumah tangga

Keluarga memiliki pengaruh yang besar kepada konsumen anggota keluarga akan saling mempengaruhi dalam pengambilan keputusan pembelian produk dan jasa. Pengambilan keputusan pembelian suatu produk dan jasa tersebut mempengaruhi oleh anggota keluarga lain atau diputuskan oleh beberapa anggota keluarga atau diputuskan bersama oleh semua anggota keluarga (A. K. K. Sari 2013).

d) Kelompok acuan

Kelompok mempengaruhi proses pembelian ddalam dua cara :

(1) Kelompok mempengaruhi pembelian yang dibuat oleh seorang konsumen

(2) Anggota-anggota kelompok sering kali membuat keputusan bersamsama sebagai sebuah kelompok (Sumarwan 2011)

e) Lingkungan dan situasi konsumsi Lingkungan konsumen terbagi menjadi dua macam :

(1) Lingkungan social adalah semua interaksi social yang terjadi antara konsumen dengan orang sekelilingnya atau anatara banyak orang.

(2) lingkungan fisik adalah segala sesuatu yang berbentuk fisik sekeliling konsumen, termasuk didalamnya adalah beragam produk, toko, maupun lokasi took (Firmansyah 2019)

f) Pengaruh teknologi terhadap keputusan konsumen

Kemajuan teknologi sangat berpengaruh terhadap perubahan perilaku konsumen secara signifikan (Firmansyah and Fatihudin 2017).

\section{Tabungan}

Menurut undang-undang perbankan syariah nomor 21 tahun 2008, tabungan adalah simpanan berdasarkan akad wadi'ah atau investasi dana berdasarkan mudharabah atau akad lain yang tidak bertentangan dengan prinsip syariah yang penarikannya dapat dilakukan menurut syarat dan ketentuan tertentu yang disepakati, tetapi tidak dapat ditarik dengan cek, bilyet giro, atau alat lainnya yang di persamakan dengan itu (AlArif and Hamidawati 2011).

Sedangkan menurut bahasa tabungan adalah bentuk simpanan nasabah yang bersifat likuid, hal ini memberikan arti produk ini dapat diambil sewaktu-waktu apabila nasabah membutuhkan, namun bagi hasil yang ditawarkan kepada nasabah penabung kecil.

\section{B. Perbandingan Penelitian Terdahulu}

Penelitian tentang pengaruh kualitas produk dan promosi terhadap keputusan nasabah memilih tabungan amanah di BMT Purwakarta Amanah Sejahtera, sudah banyak dilakukan penelitian oleh peneliti sebelumnya, seperti penelitian-penelitian sebagai berikut:

A. Pengaruh Kualitas Produk Dan Promosi Terhadap Keputusan Pembelian Produk Tabungan Pada PT. Bank Tabungan 
Negara (Persero), Tbk. Kantor Cabang Kelapa Gading Square (Setiawan and Wiwaha 2020)

PT. Bank Tabungan Negara (Persero), Tbk., yang biasa dikenal dengan BTN adalah sebuah perseroan terbatas yang bergerak dibidang penyedia jasa perbankan. Sebagai lembaga keuangan harus mampu bersaing dalam hal layanan dan produk perbankan serta promosi yang ditawarkan untuk mendorong dana simpanan dan meningkatkan fee based income. Penelitian ini membahas masalah pengaruh variasi produk dan promosi terhadap keputusan pembelian produk tabungan. Tujuan penelitian ini adalah untuk mengetahui besarnya pengaruh kualitas produk dan promosi secara simultan terhadap keputusan pembelian produk tabungan pada PT. Bank Tabungan Negara (Pesero), Tbk. Metode penelitian yang digunakan Library Research dan Field Research. Penelitian dimulai Maret s.d Juli 2019, dilaksanakan pada PT. Bank Tabungan Negara (Persero) Tbk. Kantor Cabang Kelapa Gading Square. Sampel yang digunakan dalam penelitian ini berjumlah 161 orang nasabah. Teknik pengumpulan data menggunakan wawancara, angket dan observasi. Untuk menghitung dan menganalisis data penelitian digunakan program SPSS. Hasil penelitian menunjukkan kualitas produk dan promosi berpengaruh positif dan signifikan secara simultan terhadap keputusan pembelian produk tabungan pada PT. Bank BTN Kantor Cabang Kelapa Gading Square sebesar $62 \%$.

Perbedaan penelitian terdahulu dengan penelitian saat ini, pertama, lokasi penelitian yang berbeda, peneliti terdahulu berlokasi di PT. Bank Tabungan Negara (Persero), Tbk. Kantor Cabang Kelapa Gading Square, sedangkan penelitian saat berlokasi di BMT Purwakarta Amanah Sejahtera. Kedua, variable terikat $(\mathrm{Y})$ penelitian terdahulu menggunakan Keputusan Pembelian Produk
Tabungan, sedangkan penelitian saat ini variable terikat menggunakan keputusan nasabah memilih tabungan amanah. Ketiga, jumlah sampel yang digunakan pada penelitian terdahulu sebanyak 161 responden, sedangkan pada penelitian saat ini sebanyak 52 orang dari total populasi 110 orang.

\section{B. Pengaruh Kualitas Pelayanan Dan} Kualitas Produk Tabungan iB Hasanah Terhadap Kepuasan Nasabah Pada PT Bank BNI Syariah Kantor Cabang Medan (Rahfizah, Supaino, and Kholil 2020)

Penelitian tersebut dilakukan untuk mengetahui pengaruh kualitas pelayanan dan kualitas produk tabungan iB Hasanah terhadap kepuasan nasabah pada PT Bank BNI Syariah Kantor Cabang Medan. Variabel dependen dalam penelitian ini adalah kepuasan nasabah sedangkan variabel independen terdiri dari kualitas pelayanan dan kualitas produk tabungan iB Hasanah. Sampel yang digunakan dalam penelitian ini sebanyak 100 orang Penelitian ini menggunakan kuisioner sebagai data primer kemudian hasil datanya dianalisis menggunakan regresi berganda dengan melakukan uji simultan (F), uji determinasi, dan uji parsial (t) dengan tingkat signifikan sebesar 5 persen $(\alpha=0,05)$ yang diolah dengan bantuan alat SPSS 22 . Hasil penelitian ini menunjukkan adanya pengaruh positif dan signifikan secara simultan antara kualitas pelayanan dan kualitas produk tabungan iB Hasanah terhadap kepuasan nasabah pada PT Bank BNI Syariah Kantor Cabang Medan yang dilihat melalui uji statistik $\mathrm{F}$ dengan nilai signifikansi sebesar 0,000. Hasil uji statistik t menunjukkan bahwa kualitas pelayanan tidak berpengaruh positif dan tidak signifikan dengan tingkat signifikansi sebesar 0,935 dan kualitas produk tabungan iB Hasanah berpengaruh positif dan signifikan dengan tingkat signifikansi sebesar 0,000. 
Perbedaan penelitian terdahulu dengan penelitian saat ini, pertama, lokasi penelitian yang berbeda, peneliti terdahulu berlokasi di PT Bank BNI Syariah Kantor Cabang Medan, sedangkan penelitian saat berlokasi di BMT Purwakarta Amanah Sejahtera. Kedua, variable $\mathrm{X}_{1}$ dan $\mathrm{X}_{2}$ penelitian terdahulu menggunakan kualitas pelayanan $\left(\mathrm{X}_{1}\right)$ dan kualitas produk tabungan ib hasanah $\left(\mathrm{X}_{2}\right)$, sedangkan pada penelitian saat ini variable $\mathrm{X}_{1}$ kualitas produk dan $\mathrm{X}_{2}$ kualitas promosi. Ketiga, jumlah sampel yang digunakan pada penelitian terdahulu sebanyak 100 responden, sedangkan pada penelitian saat ini sebanyak 52 orang dari total populasi 110 orang.

C. Pengaruh Kualitas Pelayanan dan Keunggulan Produk iB Hasanah Terhadap Kepuasan Nasabah pada PT Bank BNI Syariah Malang (Rini, Hufron, and Wahono 2020)

Penelitian ini bertujuan untuk: mengidentifikasi dan menganalisis variabel bukti langsung, kehandalan, daya tanggap, jaminan, empati dan keunggulan produk Tabungan iB Hasanah secara simultan berpengaruh terhadap kepuasan nasabah pada PT Bank BNI Syariah Malang, (2) Mengetahui dan menganalisis bukti variabel. langsung, kehandalan, daya tanggap, jaminan, empati secara parsial mempengaruhi kepuasan nasabah pada PT Bank BNI Syariah Malang, (3) Mengetahui dan menganalisis bagaimana keunggulan produk Tabungan iB Hasanah secara parsial mempengaruhi kepuasan nasabah pada PT Bank BNI Syariah Malang. Populasi dan sampel nasabah PT Bank BNI Syariah Malang yang berjumlah 100 nasabah. Pengumpulan data menggunakan kuesioner. Dengan menggunakan metode analisis regresi linier berganda. Hasil penelitian ini menunjukkan bahwa: (1) Variabel bukti langsung, keandalan, daya tanggap, jaminan, empati dan keunggulan produk Tabungan iB Hasanah secara simultan berpengaruh terhadap kepuasan nasabah pada PT Bank BNI Syariah Malang. (2) Variabel bukti langsung, reliabilitas, daya tanggap, jaminan, empati secara parsial berpengaruh terhadap kepuasan nasabah pada PT Bank BNI Syariah Malang. (3) keunggulan produk Tabungan iB Hasanah berpengaruh parsial terhadap kepuasan nasabah pada PT Bank BNI Syariah Malang.

Perbedaan penelitian terdahulu dengan penelitian saat ini, pertama, peneliti terdahulu berlokasi di PT Bank BNI Syariah Malang, sedangkan penelitian saat berlokasi di BMT Purwakarta Amanah Sejahtera. Kedua, variable $\mathrm{X}_{1}$ dan $\mathrm{X}_{2}$ penelitian terdahulu menggunakan kualitas pelayanan $\left(\mathrm{X}_{1}\right)$ dan keunggulan produk iB Hasanah $\left(\mathrm{X}_{2}\right)$, sedangkan pada penelitian saat ini variable $\mathrm{X}_{1}$ kualitas produk dan $\mathrm{X}_{2}$ kualitas promosi. Ketiga, jumlah sampel yang digunakan pada penelitian terdahulu sebanyak 100 responden, sedangkan pada penelitian saat ini sebanyak 52 orang dari total populasi 110 orang.

D. Pengaruh Kualitas Layanan dan Kualitas Produk Terhadap Kepuasan Nasabah Bank (Andriyani and Ardianto 2020)

Bank sebagai perusahaan jasa sangat mementingkan kepuasan melalui layanan dan produk. Tujuan penelitian ini untuk mengetahui pengaruh kualitas layanan dan kualitas produk terhadap kepuasan nasabah. Penelitian dilakukan dengan menyebar kuesioner kepada 100 responden yaitu nasabah Bank yang bertempat tinggal dan memiliki rekening Bank di daerah Cibubur. Data penelitian dianalisis menggunakan analisis regresi linier ganda. Penelitian menghasilkan temuan bahwa kualitas layanan tidak berpengaruh terhadap kepuasan nasabah sedangkan kualitas produk berpengaruh terhadap kepuasan nasabah dengan arah positif. 
Perbedaan penelitian terdahulu dengan penelitian saat ini, pertama, lokasi penelitina peneliti terdahulu nasabah Bank yang bertempat tinggal dan memiliki rekening Bank di daerah Cibubur, sedangkan penelitian saat berlokasi di BMT Purwakarta Amanah Sejahtera. Kedua, variable $\mathrm{X}_{1}$ dan $\mathrm{X}_{2}$ penelitian terdahulu menggunakan Kualitas Layanan $\left(\mathrm{X}_{1}\right)$ dan Kualitas Produk $\left(\mathrm{X}_{2}\right)$, sedangkan pada penelitian saat ini variable $\mathrm{X}_{1}$ kualitas produk dan $\mathrm{X}_{2}$ kualitas promosi. Ketiga, jumlah sampel yang digunakan pada penelitian terdahulu sebanyak 100 responden, sedangkan pada penelitian saat ini sebanyak 52 orang dari total populasi 110 orang. Keempat, variable terikat (Y) penelitian terdahulu menggunakan kepuasan nasabah bank, sedangkan penelitian saat ini variable terikat menggunakan keputusan nasabah memilih tabungan amanah.

E. Pengaruh Persepsi Bagi Hasil, Promosi Dan Kualitas Pelayanan Terhadap Minat Penggunaan Jasa Perbankan Syariah Tabungan Mudharabah Pada Mahasiswa Universitas Potensi Utama (Risal and Alexander 2019)

Penelitian tersebut bertujuan untuk mengetahui pengaruh persepsi terhadap variabel Bagi Hasil, Promosi, dan Kualitas Pelayanan secara per individu (partial) maupun secara bersama-sama (simultan) pada mahasiswa Fakultas Ekonomi dan Bisnis Universitas Potensi Utama terhadap Keputusan penggunaan Jasa Perbankan Syariah Tabungan Mudharabah. Pengambilan sampel menggunakan teknik purpossive sampling sebanyak 100 responden mahasiswa Fakultas Ekonomi dan Bisnis Universitas Potensi Utama. Berdasarkan analisis regresi pada tarif signifikan 5\% menunjukkan (1) terdapat pengaruh positif dan signifikan Bagi Hasil terhadap Keputusan dengan koefisien korelasi rx1y sebesar 0,617; koefisien determinasi r2x1y sebesar 0,413; dan nilai signifikansi $\quad 0,000<0,05 ; \quad$ (2) terdapat pengaruh positif dan signifikan Promosi terhadap Keputusan, dengan koefisien korelasi rx2y sebesar 0,681; koefisien determinasi $\mathrm{r} 2 \mathrm{x} 2 \mathrm{y}$ sebesar 0,471 ; dan nilai signifikansi $\quad 0,000<0,05 ; \quad$ (3) terdapat pengaruh positif dan signifikan Kualitas Pelayanan terhadap Keputusan, dengan koefisien korelasi rx3y sebesar 0,456; koefisien determinasi $\mathrm{r} 2 \mathrm{x} 3 \mathrm{y}$ sebesar 0,502 ; dan nilai signifikansi $0,000<0,05$; dan (4) terdapat pengaruh positif dan signifikan Bagi Hasil, Promosi, Kualitas Pelayanan secara bersama- sama terhadap Keputusan, dengan koefisien korelasi $\operatorname{Rxy}(1,2,3)$ sebesar 0,795 dan koefisien determinasi nilai R2 xy $(1,2,3)$ sebesar 0,632; dan Fhitung sebesar 54,907 lebih besar dari Ftabel sebesar 2,70.

Perbedaan penelitian terdahulu dengan penelitian saat ini, pertama, lokasi penelitian peneliti terdahulu pada kalangan mahasiswa Universitas Potensi Utama, sedangkan penelitian saat berlokasi di BMT Purwakarta Amanah Sejahtera. Kedua, variable $\mathrm{X}_{1}$ dan $\mathrm{X}_{2}$ penelitian terdahulu menggunakan persepsi bagi hasil $\left(\mathrm{X}_{1}\right)$ dan promosi $\left(\mathrm{X}_{2}\right)$ dan kualitas pelayanan $\left(\mathrm{X}_{3}\right)$, sedangkan pada penelitian saat ini variable $X_{1}$ kualitas produk dan $X_{2}$ kualitas promosi. Ketiga, jumlah sampel yang digunakan pada penelitian terdahulu sebanyak 100 responden, sedangkan pada penelitian saat ini sebanyak 52 orang dari total populasi 110 orang. Keempat, variable terikat (Y) penelitian terdahulu menggunakan minat penggunaan jasa perbankan syariah tabungan mudharabah, sedangkan penelitian saat ini variable terikat menggunakan keputusan nasabah memilih tabungan amanah.

\section{METODOLOGI PENELITIAN}

Penelitian saat ini penulis menggunakan metode penelitian kuantitaif. Metode penelitian kuantitaif dapat diartikan sebagai 
metode penelitian yang berlandaskan pada filsafat positivisme, digunakan untuk meneliti pada populasi atau sampel tertentu, teknik pengambilan sampel pada umumnya dilakukan secara random, pengumpulan data menggunakan istrument penelitian, analisis data bersifat kuantitatif/statistic dengan tujuan utnuk menguji hipotesis yang telah ditetapkan (Sugiyono 2008).

Sumber data primer yaitu yang penulis dapatkan melalui wawancara kepada pihak BMT Purwakarta Amanah Sejahtera, observasi dilapangan yang berhubungan dengan judul penelitian, dan kusioner untuk nasabah tabungan amanah.

Sumber data sekunder didapatkan melalui buku, artikel, karya ilmiah atau internet. Adapun sumber data sekunder yang digunakan oleh penulis adalah pengambilan beberapa data disitus resmi BMT Purwakarta Amanah Sejahtera. Jenis data yang digunakan oleh peneliti adalah jenis data kuantitaif, karena peneliti menggunakan data berupa angka-angka.

Metode angket atau kuesioner adalah sejumlah pertanyaan tertulis yang digunakan untuk memperoleh informasi dari responden dalam arti laporan tentang pribadinya, atau hal-hal yang ia ketahui (Arikunto 2002).

Peneliti menggunakan metode ini untuk mencari data yang berhubungan langsung dengan keadaan subjek yang berupa pengaruh kualitas produk dan promosi tehadap tabungan amanah di BMT Purwakarta Amanah Sejahtera. Angket atau kuesioner disebarkan pada responden yaknik nasabah tabungan amanah sebanyak 52 orang penggunakaan angket sebagai pengumpulan data.

Definisi operasional variabel penelitian adalah suatu artribut atau sifat atau nilai dari orang, objek atau kegiatan yang mempunyai variasi tertentu yang ditetapkan oleh peneliti untuk dipelajari dengan kemudian ditarik kesimpulannya (Sugiyono 2006). Penelitian ini menggunakan dua variabel, yaitu :

1. Variabel Bebas

Variabel bebas (Independence variabel) adalah variabel yang mempengaruhi atau yang menjadi sebab perubahannya atau timbulnya variabel dependen (terikat). Variabel bebas (X) dalam penelitian ini adalah kualitas produk dan promosi. Pengumpulan informasi mengenai variabel ini berdasarkan kuesioner berupa daftar pertanyaan yang diajukan kepada responden.

\section{Variabel terikat}

Variabel terikat adalah variabel yang dipengaruhi atau yang menjadi akibat, karna adanya variabel bebas. Variabel terikat (Y) yang digunakan adalah keputusan nasabah. Pengumpulan informasi mengenai variabel ini berdasarkan kuesioner, berupaya daftar pertanyaan yang diajukan kepada responden (Sugiyono 2015).

Tabel 3.1

Operasinal Variabel

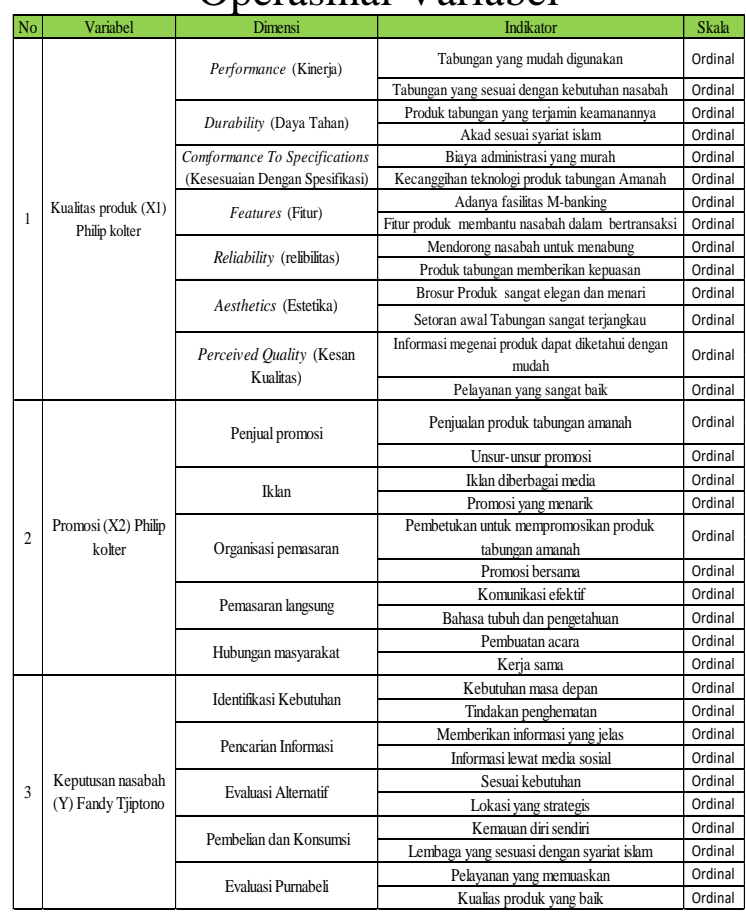

Di Susun Oleh Penulis

Populasi adalah wilayah generalisasi yang

EKSISBANK (Ekonomi Syariah dan Bisnis Perbankan), Volume 5, Nomor 2, Desember 2021 
terdiri dari atas obyek/ subjek yang mempunyai kualitas dan karakteristik tertentu yang ditetapkan oleh peneliti untuk dipelajari dan kemudian ditarik kesimpulannya (Sugiyono 2017). Populasi dalam penelitian ini adalah nasabah tabungan amanah. Besarnya populasi yang ada di BMT PAS pada tahun 2019 sebanyak 110 nasabah tabungan amanah.

Sampel dalam penelitian ini adalah sebagian nasabah tabungan amanah. Teknik pengambilan sampel untuk menentukan sampel yang akan digunakan dalam penelitian ini menggunakan teknik non probability sampling, yaitu purposive sampling. Purposive sampling adalah cara pengambilan sampel berdasarkan karakteristik tertentu seperti nasabah tabungan amanah. Dalam menentukan sampel pada penelitian ini, penulis menggunakan teknik Slovin yaitu dengan rumus :

$$
\begin{aligned}
& \mathrm{n}=\frac{\mathrm{N}}{1+\left(\mathrm{nx} \mathrm{e}^{2}\right)} \\
& \mathrm{n}=\frac{110}{1+(110 \times 0,01)} \\
& \mathrm{n}=52,38 \\
& \text { Dengan Ketentuan : } \\
& \mathrm{n}=\text { Jumlah Sampel } \\
& \mathrm{N}=\text { Jumlah Populasi } \\
& \mathrm{e}=\text { Toleransi Kesalahan }
\end{aligned}
$$

Dengan demikian, maka dari jumlah populasi 110 diperoleh ukuran sampel sebesar 52,38 atau dibulatkan menjadi 52 sampel penelitian.

\section{HASIL DAN PEMBAHASAN \\ A. Hasil Uji Statistik}

\section{Uji Validitas}

Uji validitas yaitu suatu instrument dikatakan valid apabila mampu mengukur apa yang diinginkan serta dapat mengungkapkan data dari variabel yang diteliti dengan tepat. Uji validitas digunakan untuk mengukur sah atau tidak sahnya suatu kuesioner. Suatu kuesioner dikatakan valid jika pernyataan dikuesioner mampu untuk mengungkapkan suatu yang akan diukur oleh kuesioner tersebut.

Berdasarkan hasil analisis validitas intrumen kualitas produk, promosi, dan keputusan nasabah dari 34 item pernyataan pada angket yang diajukan pada 52 responden ternyata seluruh soal dinyatakan valid. Item soal dikatakan valid sebab memiliki nilai rhitung lebih besar dari rtabel $(0,279)$. Berikut ini adalah hasil dari uji validitas tersebut.

Tabel 4.2

Uji Validitas Kualitas Produk $\left(\mathrm{X}_{1}\right)$ Pengaruh Kualitas Produk Dan Promosi Terhadap Keputusan Nasabah

\begin{tabular}{|c|c|c|c|c|}
\hline $\begin{array}{c}\text { No } \\
\text { Soal }\end{array}$ & rhitung & Sig & rtabel & Kesimpulan \\
\hline 1 & 0,481 & 0,000 & 0,279 & Valid \\
\hline 2 & 0,410 & 0,003 & 0,279 & Valid \\
\hline 3 & 0,402 & 0,003 & 0,279 & Valid \\
\hline 4 & 0,386 & 0,005 & 0,279 & Valid \\
\hline 5 & 0,342 & 0,013 & 0,279 & Valid \\
\hline 6 & 0,618 & 0,000 & 0,279 & Valid \\
\hline 7 & 0,499 & 0,000 & 0,279 & Valid \\
\hline 8 & 0,400 & 0,003 & 0,279 & Valid \\
\hline 0 & 0,311 & 0,025 & 0,279 & Valid \\
\hline 10 & 0,288 & 0,038 & 0,279 & Valid \\
\hline 11 & 0,387 & 0,005 & 0,279 & Valid \\
\hline 12 & 0,400 & 0,003 & 0,279 & Valid \\
\hline 13 & 0,447 & 0,001 & 0,279 & Valid \\
\hline 14 & 0,481 & 0,000 & 0,279 & Valid \\
\hline
\end{tabular}

Sumber: Diolah Oleh Data SPSS

Berdasarkan uji validitas yang telah dilakukan untuk menguji masing-masing butir pernyataan di variabel X1 (Kualitas Produk) dengan Sig dibawah 0,05 diperoleh hasil bahwa nilai rhitung > rtabel $(0,279)$, maka diperoleh kesimpulan bahwa hasil seluruh butir pernyataan dinyatakan valid.

Tabel 4.3

Uji Validitas Promosi (X2)

EKSISBANK (Ekonomi Syariah dan Bisnis Perbankan), Volume 5, Nomor 2, Desember 2021 
Pengaruh Kualitas produk Dan Promosi terhadap Keputusan Nasbah Tabungan Amanah

\begin{tabular}{|c|c|c|c|c|}
\hline $\begin{array}{c}\text { No } \\
\text { Soal }\end{array}$ & rhitung & Sig & rtabel & Kesimpulan \\
\hline 1 & 0,349 & 0,011 & 0,279 & Valid \\
\hline 2 & 0,471 & 0,000 & 0,279 & Valid \\
\hline 3 & 0,628 & 0,000 & 0,279 & Valid \\
\hline 4 & 0,516 & 0,000 & 0,279 & Valid \\
\hline 5 & 0,710 & 0,000 & 0,279 & Valid \\
\hline 6 & 0,480 & 0,000 & 0,279 & Valid \\
\hline 7 & 0,492 & 0,000 & 0,279 & Valid \\
\hline 8 & 0,285 & 0,041 & 0,279 & Valid \\
\hline 0 & 0,481 & 0,000 & 0,279 & Valid \\
\hline 10 & 0,483 & 0,000 & 0,279 & Valid \\
\hline
\end{tabular}

Sumber: Diolah Oleh Data SPSS

Berdasarkan uji validitas yang telah dilakukan untuk menguji masing-masing butir pernyataan di variabel X2 (Promosi) dengan Sig dibawah 0,05 diperoleh hasil bahwa nilai rhitung > rtabel $(0,279)$, maka diperoleh kesimpulan bahwa hasil seluruh butir pertanyaan dinyatakan valid.

Tabel 4.4

Uji Validitas Keputusan Nasabah (Y) Pengaruh Kualitas produk Dan Promosi terhadap Keputusan Nasabah Tabungan

Amanah

\begin{tabular}{|c|c|c|c|c|}
\hline $\begin{array}{c}\text { No } \\
\text { Soal }\end{array}$ & rhitung & Sig & rtabel & Kesimpulan \\
\hline 1 & 0,358 & 0,009 & 0,279 & Valid \\
\hline 2 & 0,451 & 0,001 & 0,279 & Valid \\
\hline 3 & 0,484 & 0,000 & 0,279 & Valid \\
\hline 4 & 0,695 & 0,000 & 0,279 & Valid \\
\hline 5 & 0,682 & 0,000 & 0,279 & Valid \\
\hline 6 & 0,671 & 0,000 & 0,279 & Valid \\
\hline 7 & 0,430 & 0,001 & 0,279 & Valid \\
\hline 8 & 0,354 & 0,010 & 0,279 & Valid \\
\hline 9 & 0,467 & 0,000 & 0,279 & Valid \\
\hline 10 & 0,298 & 0,032 & 0,279 & Valid \\
\hline
\end{tabular}

Sumber: Diolah Oleh Data SPSS

Berdasarkan uji validitas yang telah dilakukan untuk menguji masing-masing butir pernyataan di variabel Y (Keputusan Nasabah) dengan Sig dibawah 0,05 diperoleh hasil bahwa nilai rhitung > rtabel $(0,279)$, maka diperoleh kesimpulan bahwa hasil seluruh butir pertanyaan dinyatakan valid.

\section{Uji Reliabilitas}

Analisis ini digunakan untuk mengetahui sejauh mana pengukur data dapat memberikan hasil relativ konsisten atau tidak, berbeda jika diukur ulang pada subjek yang sama, sehingga dapat diketahui konsisten atau keterangan dalam alat ukur kuesioner. Instrumen penelitian dikatakan reliable jika nilai cronbach alpha $>0,60$

a. Realiabilitas Instrumen Variabel $\mathrm{X}_{1}$ (Kualitas Produk)

Hasil uji reliabilitas variabel $\mathrm{X}_{1}$ (Kualitas Produk), dapat dilihat dari tabel di bawah ini

Tabel 4.5

Hasil Uji Reabilitas Instrumen Variabel $X_{1}$ (Kualitas Produk)

\begin{tabular}{|l|l|}
\hline \multicolumn{2}{|c|}{ Reliability Statistics } \\
\hline Cronbach's Alpha & N of Items \\
\hline, 632 & 14 \\
\hline
\end{tabular}

Sumber: diolah oleh SPSS

Hasil uji reliabilitas variabel $\mathrm{X}_{1}$ (Kualitas Produk) diperoleh nilai cronbach's alpha sebesar $(0,632)$ lebih besar darI $(0,60)$ menunjukan bahwa intrumen variabel kualitas produk dinyatakan reliable. Maka dengan demikian, sebanyak 14 item pernyataan dinyatakan dapat digunakan untuk pengumpulan data peneltian variabel kualitas produk.

b. Realiabilitas Instrumen Variabel $\mathrm{X}_{2}$ (Promosi)

Hasil uji reliabilitas variabel $\mathrm{X}_{2}$ (Promosi), dapat dilihat dari tabel di bawah ini :

EKSISBANK (Ekonomi Syariah dan Bisnis Perbankan), Volume 5, Nomor 2, Desember 2021 http://journal.sties-purwakarta.ac.id/index.php/EKSISBANK/ 
Tabel 4.6

Hasil Uji Reabilitas Instrumen Variabel X2 (Promosi).

\begin{tabular}{|l|l|}
\hline \multicolumn{2}{|c|}{ Reliability Statistics } \\
\hline Cronbach's Alpha & \multicolumn{1}{c|}{ N of Items } \\
\hline, 621 & 10 \\
\hline
\end{tabular}

Sumber: Diolah Oleh Data SPSS

Hasil uji reliabilitas variabel X2 (Promosi) diperoleh nilai cronbach's alpha sebesar $(0,621)$ lebih besar darI $(0,60)$ menunjukan bahwa intrumen variabel promosi dinyatakan reliable. Maka dengan demikian, sebanyak 10 item pernyataan dinyatakan dapat digunakan untuk pengumpulan data peneltian variabel promosi.

c. Realiabilitas Instrumen Variabel $\mathrm{Y}$ (Keputusan Nasabah)

Hasil uji reliabilitas variabel $\mathrm{Y}$ (Keputusan Nasabah), dapat dilihat dari tabel di bawah ini :

Tabel 4.7

Hasil Uji Reabilitas Instrumen Variabel Y

(Keputusan Nasabah)

\begin{tabular}{|l|l|}
\hline \multicolumn{2}{|c|}{ Reliability Statistics } \\
\hline Cronbach's Alpha & \multicolumn{1}{c|}{ N of Items } \\
\hline 670 & 10 \\
\hline
\end{tabular}

Sumber: Diolah Oleh Data SPSS

Hasil uji reliabilitas variabel Y (Keputusan Nasabah) diperoleh nilai cronbach's alpha sebesar $(0,670)$ lebih besar darI $(0,60)$ menunjukan bahwa intrumen variabel keputusan nasabah dinyatakan reliable. Maka dengan demikian, sebanyak 10 item pernyataan dinyatakan dapat digunakan untuk pengumpulan data peneltian variabel keputusan nasabah.

\section{Uji Normalitas}

Uji normalitas bertujuan untuk menguji apakah dalam model regresi, variabel terikat dan variabel bebas keduanya memiliki distribusi normal atau tidak. a. Hasil Uji Normalitas Data Variabel X1 (Kualitas Produk)

Uji normalitas variabel X1 (Kualitas Produk) menggunakan one sample Kolmogorov smirnov-test. Hasil analisis uji normalitas data sebagai berikut :

Tabel 4.8

Uji Normalitas Variabel X1 (Kualitas

Produk)

\begin{tabular}{|c|c|c|}
\hline \multicolumn{3}{|c|}{ One-Sample Kolmogorov-Smirnov Test } \\
\hline & & $\begin{array}{l}\text { Unstandardized } \\
\text { Residual }\end{array}$ \\
\hline \multicolumn{2}{|l|}{$\mathrm{N}$} & 52 \\
\hline \multirow{2}{*}{$\begin{array}{l}\text { Normal } \\
\text { Parameters }{ }^{\mathrm{a}, \mathrm{b}}\end{array}$} & Mean & 0E-7 \\
\hline & Std. Deviation & 2,96065455 \\
\hline \multirow{3}{*}{$\begin{array}{l}\text { Most Extreme } \\
\text { Differences }\end{array}$} & Absolute &, 069 \\
\hline & Positive &, 069 \\
\hline & Negative &,- 052 \\
\hline \multicolumn{2}{|c|}{ Kolmogorov-Smirnov Z } & 494 \\
\hline \multicolumn{2}{|c|}{ Asymp. Sig. (2-tailed) } & 968 \\
\hline \multicolumn{3}{|c|}{ a. Test distribution is Normal. } \\
\hline
\end{tabular}

Sumber: Diolah Oleh Data SPSS

Berdasarkan uji normalitas menggunakan one sample Kolmogorov smirnov-test.dengan nilai Asymp. Sig. sebesar 0,968 (0,968> 0,05), dengan demikian dapat disimpulkan bahwa data variabel kualitas produk berdistribusi normal

b. Hasil Uji Normalitas Data Variabel X2 (Promos)

Uji normalitas variabel X2 (Promosi) menggunakan one sample Kolmogorov smirnov-test. Hasil analisis uji normalitas data sebagai berikut :

Tabel 4.9

Uji Normalitas Variabel X2 (Promosi) One-Sample Kolmogorov-Smirnov Test

\begin{tabular}{|c|c|c|}
\hline \multicolumn{3}{|c|}{ One-Sample Kolmogorov-Smirnov Test } \\
\hline & & \begin{tabular}{|c|} 
Unstandardized \\
Residual
\end{tabular} \\
\hline \multicolumn{2}{|l|}{$\mathrm{N}$} & 52 \\
\hline \multirow{2}{*}{$\begin{array}{l}\text { Normal } \\
\text { Parameters }{ }^{\mathrm{a}, \mathrm{b}}\end{array}$} & Mean & 0E-7 \\
\hline & Std. Deviation & 2,90806582 \\
\hline \multirow{3}{*}{$\begin{array}{l}\text { Most Extreme } \\
\text { Differences }\end{array}$} & Absolute & ,066 \\
\hline & Positive & ,066 \\
\hline & Negative &,- 064 \\
\hline \multicolumn{2}{|c|}{ Kolmogorov-Smirnov Z } &, 476 \\
\hline \multicolumn{2}{|c|}{ Asymp. Sig. (2-tailed) } & ,977 \\
\hline \multicolumn{3}{|c|}{ a. Test distribution is Normal. } \\
\hline \multicolumn{3}{|c|}{ b. Calculated from data. } \\
\hline
\end{tabular}

EKSISBANK (Ekonomi Syariah dan Bisnis Perbankan), Volume 5, Nomor 2, Desember 2021 http://journal.sties-purwakarta.ac.id/index.php/EKSISBANK/ ISSN: 2654-8526 (Media Online) 2599-2708 (Media Cetak) 


\section{Sumber: Diolah Oleh Data SPSS}

Berdasarkan uji normalitas menggunakan one sample Kolmogorov smirnov-test.dengan nilai Asymp. Sig. sebesar 0,977 (0,977>0,05), dengan demikian dapat disimpulkan bahwa data variabel promosi berdistribusi normal.

\section{Uji Multikolinearitas}

Uji multikolinearitas bertujuan untuk menguji apakah terdapat kolerasi antar variabel bebas (independen) dalam model regresi. Apabila nilai VIF menunjukan lebih kecil dari 10,00 dan toleransi lebih besar dari 0,10 maka model regresi terbebas dari gangguan multikolinearitas.

Tabel 4.10

Uji Multikolinearitas

\begin{tabular}{|c|c|c|c|c|c|c|c|}
\hline \multicolumn{8}{|c|}{ Coefficients $^{\mathbf{a}}$} \\
\hline \multirow{2}{*}{ Model } & \multicolumn{2}{|c|}{$\begin{array}{l}\text { Unstandardized } \\
\text { Coefficients }\end{array}$} & \multirow{2}{*}{\begin{tabular}{|c}
$\begin{array}{c}\text { Standardi } \\
\text { zed } \\
\text { Coefficie } \\
\text { nts }\end{array}$ \\
Beta
\end{tabular}} & \multirow{2}{*}{$\mathrm{t}$} & \multirow{2}{*}{ Sig. } & \multicolumn{2}{|c|}{$\begin{array}{l}\text { Collinearity } \\
\text { Statistics }\end{array}$} \\
\hline & B & $\begin{array}{l}\text { Std. } \\
\text { Error }\end{array}$ & & & & $\begin{array}{l}\text { Tolera } \\
\text { nce }\end{array}$ & VIF \\
\hline Constant & 36,399 & 12,599 & & $\begin{array}{r}2,88 \\
9 \\
\end{array}$ & ,006 & & \\
\hline $11 \begin{array}{l}\text { Kualitas } \\
\text { Produk }\end{array}$ &,- 122 & ,137 &,- 123 &,- 894 & ,376 & ,999 & 1,001 \\
\hline Promosi & ,318 & , 196 & ,223 & $\begin{array}{r}1,61 \\
8\end{array}$ &, 112 & ,999 & 1,001 \\
\hline
\end{tabular}

Sumber: Diolah Oleh Data SPSS

Berdasarkan hasil multikolinearitas diketahui bahwa seluruh variabel independen dalam penelitian ini memperoleh nilai tolerance $0,999>0,10$ dan VIF 1,001 < 10,00, maka dapat diambil kesimpulan bahwa data penelitian ini terbebas dari masalah multikolinearitas.

\section{Uji Heteroskedastisitas}

Uji Heteroskedastis bertujuan untuk menguji apakah dalam model regresi terjadi ketidak samaan variance dan residual satu pengamatan ke pengamatan lainnya.

Tabel 4.11

Uji Heteroskedastisitas

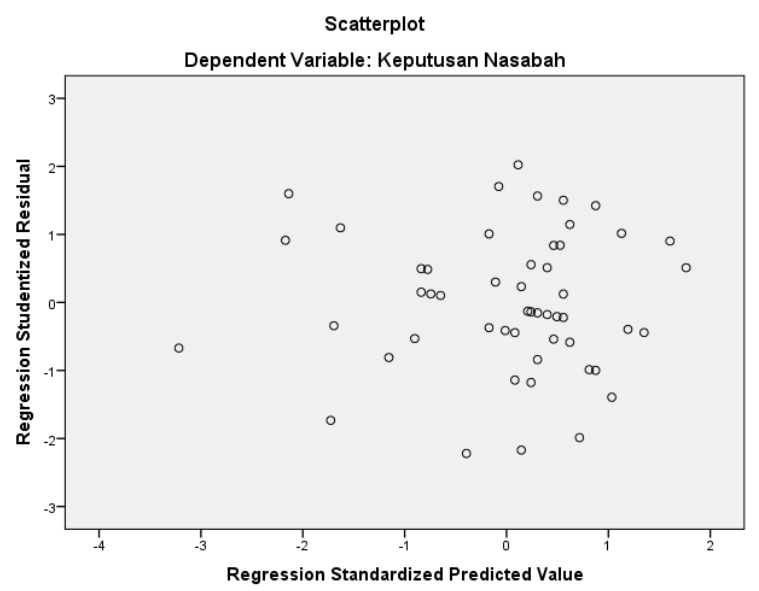

Sumber: Diolah Oleh Data SPSS

Ciri-ciri tidak terjadi heteroskedastis titik data penyebar diatas dan dibawah atau disekitar angka nol, titik-titik tidak mengumpul hanya diatas atau dibawah saja, penyebaran titik-titik data tidak boleh membentuk pola bergelombang melebar kemudian menyempit dan melebar kembali, dan penyebaran titik-titik tidak berpola. Dengan demikian dapat disimpulkan bahwa hasil uji heteroskedastis tidak terjadi gangguan heteroskedastis.

\section{Uji Hipotesis}

\section{a. Koefisien Determinasi(R2)}

Uji koefisiensi determinasi digunakan untuk mengetahui presentasi sumbangan pengaruh variabel independen terhadap variabel dependent. Koefesien determinasi pada intinya mengukur seberapa jauh kemampuan model dalam menerangkan variasi dari variabel dependen.

\section{Tabel 4.1}

Uji Determinasi Variabel X1 (Kualitas

Produk):

\begin{tabular}{|l|c|r|r|r|}
\hline \multicolumn{5}{|c|}{ Model Summary $^{\mathbf{b}}$} \\
\hline Model & $\mathrm{R}$ & R Square & $\begin{array}{c}\text { Adjusted R } \\
\text { Square }\end{array}$ & $\begin{array}{r}\text { Std. Error of } \\
\text { the Estimate }\end{array}$ \\
\hline 1 &, $130^{\mathrm{a}}$ &, 017 &,- 003 & 2,99011 \\
\hline \multicolumn{4}{|c|}{ a. Predictors: (Constant), Kualitas Produk } \\
\hline
\end{tabular}

EKSISBANK (Ekonomi Syariah dan Bisnis Perbankan), Volume 5, Nomor 2, Desember 2021 
Sumber: Diolah Oleh Data SPSS

Hasil determinasi memperlihatkan besarnya koefesien determinasi pengaruh variabel kualitas produk $\left(\mathrm{X}_{1}\right)$ terhadap keputusan nasabah (Y) di BMT Purwakarta Amanah Sejahtera sebesar 0,017 atau 1,7\%. Dengan demikian besarnya pengaruh variabel kualitas produk $\left(\mathrm{X}_{1}\right)$ terhadap keputusan nasabah (Y) di BMT Purwakarta Amanah Sejahtera sebesar $1,7 \%$. Sedangkan sisanya 98,3\% ditentukan variabel lain yang perlu diteliti lebih lanjut karena keterbatasan penelitian ini

Tabel 4.12

Uji Determinasi Variabel X2 (Promosi)

\begin{tabular}{|l|c|r|r|r|}
\hline \multicolumn{5}{|c|}{ Model Summary $^{\mathbf{b}}$} \\
\hline Model & $\mathrm{R}$ & $\mathrm{R}$ Square & $\begin{array}{c}\text { Adjusted R } \\
\text { Square }\end{array}$ & $\begin{array}{r}\text { Std. Error of } \\
\text { the Estimate }\end{array}$ \\
\hline 1 &, $227^{\mathrm{a}}$ &, 051 &, 032 & 2,93700 \\
\hline \multicolumn{4}{|l|}{ a. Predictors: (Constant), Promosi } \\
\hline
\end{tabular}

Sumber: Diolah Oleh Data SPSS

Hasil determinasi memperlihatkan besarnya koefesien determinasi pengaruh variabel promosi $\left(\mathrm{X}_{2}\right)$ terhadap keputusan nasabah (Y) di BMT Purwakarta Amanah Sejahtera sebesar 0,051 atau $5,1 \%$. Dengan demikian besarnya pengaruh variabel promosi $\left(\mathrm{X}_{2}\right)$ terhadap keputusan nasabah $(\mathrm{Y})$ di BMT Purwakarta Amanah Sejahtera sebesar 5,1\%. Sedangkan sisanya 94,9\% ditentukan variabel lain yang perlu diteliti lebih lanjut karena keterbatasan penelitian ini.

Tabel 4.13

Uji Determinasi Variabel kualitas produk $\left(\mathrm{X}_{1}\right)$ dan Promosi $\left(\mathrm{X}_{2}\right)$ Terhadap Keputusan Nasabah (Y).

\begin{tabular}{|l|c|r|r|c|}
\hline \multicolumn{5}{|c|}{ Model Summary $^{\mathbf{b}}$} \\
\hline Model & $\mathrm{R}$ & R Square & $\begin{array}{c}\text { Adjusted R } \\
\text { Square }\end{array}$ & $\begin{array}{c}\text { Std. Error of the } \\
\text { Estimate }\end{array}$ \\
\hline 1 &, $258^{\mathrm{a}}$ &, 067 &, 029 & 2,94290 \\
\hline a. Predictors: (Constant), Promosi, Kualitas Produk \\
\hline \multicolumn{2}{|l|}{ b. Dependent Variable: Keputusan Nasabah } \\
\hline
\end{tabular}

Sumber: Diolah Oleh Data SPSS
Hasil determinasi memperlihatkan besarnya koefesien determinasi pengaruh variabel kualitas produk $\left(\mathrm{X}_{1}\right)$ dan Promosi $\left(\mathrm{X}_{2}\right)$ Terhadap Keputusan Nasabah (Y) di BMT Purwakarta Amanah Sejahtera sebesar 0,067 atau $6,7 \%$. Dengan demikian besarnya pengaruh variabel kualitas produk $\left(\mathrm{X}_{1}\right)$ dan Promosi $\left(\mathrm{X}_{2}\right)$ Terhadap Keputusan Nasabah (Y) di BMT Purwakarta Amanah Sejahtera sebesar 6,7\%. Sedangkan sisanya 93,3\% ditentukan variabel lain yang perlu diteliti lebih lanjut karena keterbatasan penelitian ini.

\section{b. Uji Regresi Linier Berganda}

Regresi linier berganda merupakan teknik analisis regresi yang memiliki satu variabel dependen dan dua atau lebih variabel independent.

\section{Tabel 4.14}

Persamaan Regresi Variabel $\mathrm{X}_{1}$ Dan $\mathrm{X}_{2}$

Terdapat Y

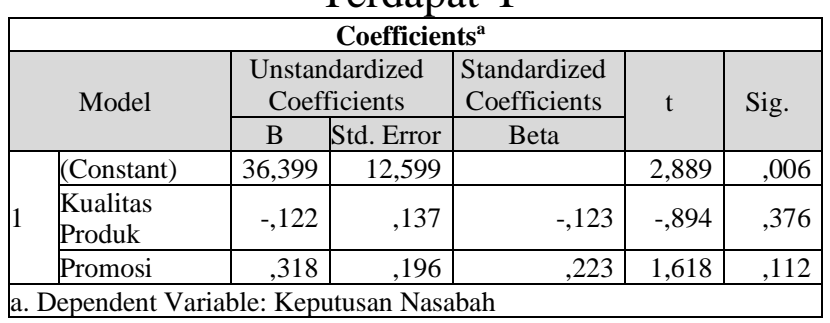

Sumber : diolah oleh SPSS

Berdasarkan tabel diatas, hasil perhitungan analisis persamaan regresi dapat diuraikan sebagai berikut :

$$
\mathrm{Y}=12,599+0,137+0,196
$$

1) Nilai konstanta diperoleh nilai sebesar 12,599 artinya jika tidak ada kualitas produk dan promosi maka nilai konstan dari peningkatan jumlah nasabah adalah sebesar 12,599

2) Angka koefisiensi regresi dari kualitas produk adalah sebesar 0,137 , artinya setiap penambahan $1 \%$ dari kualitas produk maka nilai dari peningkatan jumlah nasabah akan meningkatkan sebesar 0,137 
3) Angka koefisiensi regresi dari promosi adalah sebesar 0,196, artinya setiap penambahan $1 \%$ dari harga maka nilai dari peningkatan jumlah nasabah akan meningkat sebesar 0,196.

\section{c. Uji Persial (Uji t)}

Analisis pengujian individual atau Persial (uji t) diperlukan untuk mengetahui bahwa variabel independen secara parsial mempunyai pengaruh yang signifikan terhadap variabel dependen.

Tabel 4.15

Uji t (Parsial) Variabel $X_{1}$ dan $X_{2}$ Terhadap $\mathrm{Y}$.

\begin{tabular}{|c|c|c|c|c|c|}
\hline \multicolumn{6}{|c|}{ Coefficients $^{\mathrm{a}}$} \\
\hline \multirow[t]{2}{*}{ Model } & \multicolumn{2}{|c|}{$\begin{array}{l}\text { Unstandardized } \\
\text { Coefficients }\end{array}$} & \multirow{2}{*}{\begin{tabular}{|c|}
$\begin{array}{l}\text { Standardized } \\
\text { Coefficients }\end{array}$ \\
Beta \\
\end{tabular}} & \multirow[t]{2}{*}{$\mathrm{t}$} & \multirow[t]{2}{*}{ Sig. } \\
\hline & $\mathrm{B}$ & Std. Error & & & \\
\hline \begin{tabular}{|l|} 
(Constant) \\
\end{tabular} & 36,399 & 12,599 & & 2,889 &, 006 \\
\hline 1 Kualitas Produk &,- 122 & ,137 &,- 123 &,- 894 & ,376 \\
\hline Promosi & 318 &, 196 & 223 & 1,618 &, 112 \\
\hline
\end{tabular}

Sumber : diolah oleh SPSS

Memperoleh nilai $\mathrm{t}$ tabel :

$\mathrm{DF}=(\mathrm{n}-\mathrm{k}-1)=52-2-1=49$

Nilai $\mathrm{t}$ tabel $=2,000$

Berdasarkan hasil uji parsial dapat diperoleh kesimpulan bahwa :

1) Kualitas produk memperoleh thitung sebesar $-0,894<2,000$ dan nilai signifikasi sebesar $0,379>0,05$, sehingga dapat diambil kesimpulan bahwa kualitas produk tidak berpengaruh positif dan tidak signifikan terhadap keputusan nasabah, maka H0 diterima.

2) Promosi memperoleh thitung sebesar $1,618<2,000$ dan nilai signifikasi sebesar $0,112>0,05$, sehingga dapat diambil kesimpulan bahwa promosi tidak berpengaruh positif dan tidak signifikan terhadap keputusan nasabah, maka $\mathrm{H} 0$ diterima.

\section{d. Uji Simulasi (Uji F)}

Uji f dikenal dengan uji serentak untuk melihat bagaimana pengaruh semua variabel bebasnya secara bersama-sama terhadap variabel terikatnya. Uji simultan (uji f) bertujuan untuk menunjukan apakah semua variabel independen (bebas) mempengaruhi variabel dependen (terikat) secara bersama-sama atau simultan

Uji ini dapat dilakukan melalui pengamatan nilaisignifikasi pada tingkata yang digunakan. Dalam penelitian ini tingkat a yang digunakan adalah sebesar $5 \%$ dimana variabel $\mathrm{X}$ dikatakan berpengaruh simultan terhadap variabel $Y$ jika nilai.

Tabel 4.15

Uji F (Simultan Variabel $X_{1}$ Dan $X_{2}$ Terhadap Y

\begin{tabular}{|c|c|c|c|c|c|c|}
\hline \multicolumn{7}{|c|}{ ANOVA $^{a}$} \\
\hline & Model & $\begin{array}{c}\text { Sum of } \\
\text { Squares }\end{array}$ & Df & $\begin{array}{c}\text { Mean } \\
\text { Square }\end{array}$ & $\mathrm{F}$ & Sig. \\
\hline \multirow{3}{*}{1} & Regression & 30,300 & 2 & 15,150 & 1,749 &, $185^{\mathrm{b}}$ \\
\hline & Residual & 424,373 & 49 & 8,661 & & \\
\hline & Total & 454,673 & 51 & & & \\
\hline
\end{tabular}

sumber : diolah oleh SPSS

Memperoleh nilai $\mathrm{f}$ tabel :

DF $1=\mathrm{k}-1=3-1=2$

DF $2=\mathrm{N}-\mathrm{K}=52-2=50$

$\mathrm{F}$ tabel $=3,18$

Berdasarkan hasil uji f diperoleh nilai f hitung sebesar 1,749 lebih besar dengan $\mathrm{f}$ tabel sebesar 3,18, dan signifikasi sebesar 0,185 > 0,05 maka dapat disimpulkan bahwa kualitas produk dan promosi tidak berpengaruh secara simultan.

\section{B. Pembahasan}

1. Pengaruh Kualitas Produk terhadap keputusan nasabah memilih Tabungan Amanah Di BMT Purwakarta Amanah Sejahtera

Variabel kualitas produk memperoleh $t_{\text {hitung }}$ sebesar $-0,894<2,000$ dan nilai

EKSISBANK (Ekonomi Syariah dan Bisnis Perbankan), Volume 5, Nomor 2, Desember 2021 
signifikasi sebesar 0,379>0,05, sehingga dapat diambil kesimpulan bahwa kualitas produk tidak berpengaruh positif dan tidak signifikan terhadap keputusan nasabah, maka $\mathrm{H}_{0}$ diterima. Selanjutnya hasil uji determinasi sebesar 0,017 atau $1,7 \%$. Dengan demikian besarnya pengaruh variabel kualitas produk $\left(\mathrm{X}_{1}\right)$ terhadap keputusan nasabah (Y) di BMT Purwakarta Amanah Sejahtera sebesar 1,7\%. Sedangkan sisanya $98,3 \%$ ditentukan variabel lain yang perlu diteliti lebih lanjut karena keterbatasan penelitian ini.

\section{Pengaruh Promosi terhadap keputusan} nasabah memilih Tabungan Amanah Di BMT Purwakarta Amanah Sejahtera

Variabel promosi memperoleh thitung sebesar 1,618 < 2,000 dan nilai signifikasi sebesar $0,112>0,05$, sehingga dapat diambil kesimpulan bahwa promosi tidak berpengaruh positif dan tidak signifikan terhadap keputusan nasabah, maka $\mathrm{H}_{0}$ diterima. Selanjutnya hasil uji determinasi sebesar 0,051 atau $5,1 \%$. Dengan demikian besarnya pengaruh variabel promosi $\left(\mathrm{X}_{2}\right)$ terhadap keputusan nasabah (Y) di BMT Purwakarta Amanah Sejahtera sebesar $5,1 \%$. Sedangkan sisanya $94,9 \%$ ditentukan variabel lain yang perlu diteliti lebih lanjut karena keterbatasan penelitian ini.

3. Pengaruh Kualitas Produk dan Promosi terhadap keputusan nasabah memilih Tabungan Amanah Di BMT Purwakarta Amanah Sejahtera

Berdasarkan hasil uji $\mathrm{f}$ diperoleh nilai $\mathrm{f}_{\text {hitung }}$ sebesar 1,749 lebih besar dengan $\mathrm{f}_{\text {tabel }}$ sebesar 3,18, dan signifikasi sebesar
$0,185>0,05$ maka dapat disimpulkan bahwa kualitas produk dan promosi tidak berpengaruh secara simultan. Selanjutnya hasil uji determinasi sebesar 0,067 atau $6,7 \%$. Dengan demikian besarnya pengaruh variabel kualitas produk $\left(\mathrm{X}_{1}\right)$ dan Promosi $\left(\mathrm{X}_{2}\right)$ Terhadap Keputusan Nasabah (Y) di BMT Purwakarta Amanah Sejahtera sebesar 6,7\%. Sedangkan sisanya 93,3\% ditentukan variabel lain yang perlu diteliti lebih lanjut karena keterbatasan penelitian ini.

\section{KESIMPULAN}

Berdasarkan uji statistik yang telah dilakukan, pengaruh kualitas produk terhadap keputusan nasabah memilih tabungan amanah Di BMT Purwakarta Amanah Sejahtera tidak berpengaruh dan signifikan, karena variabel kualitas produk memperoleh $\mathrm{t}_{\text {hitung }}$ sebesar $0,894<2,000$ dan nilai signifikasi sebesar $0,379>0,05$, maka H0 diterima. Selanjutnya hasil uji determinasi sebesar 0,017 atau $1,7 \%$. Dengan demikian besarnya pengaruh variabel kualitas produk $\left(\mathrm{X}_{1}\right)$ terhadap keputusan nasabah (Y) di BMT Purwakarta Amanah Sejahtera sebesar $1,7 \%$. Sedangkan sisanya 98,3\% ditentukan variabel lain yang perlu diteliti lebih lanjut karena keterbatasan penelitian ini.

Pengaruh Promosi terhadap keputusan nasabah memilih Tabungan Amanah Di BMT Purwakarta Amanah Sejahtera tidak berpengaruh positif dan tidak signifikan, karena variabel promosi memperoleh $t_{\text {hitung }}$ sebesar $1,618<2,000$ dan nilai signifikasi sebesar $0,112>0,05$, maka $\mathrm{H}_{0}$ diterima. Selanjutnya hasil uji determinasi sebesar 0,051 atau $5,1 \%$. Dengan demikian besarnya pengaruh variabel promosi $\left(\mathrm{X}_{2}\right)$ terhadap keputusan nasabah (Y) di BMT Purwakarta Amanah Sejahtera sebesar $5,1 \%$. Sedangkan sisanya 94,9\% ditentukan variabel lain yang 
perlu diteliti lebih lanjut karena keterbatasan penelitian ini.

Pengaruh Kualitas Produk dan Promosi terhadap keputusan nasabah memilih Tabungan Amanah Di BMT Purwakarta Amanah Sejahtera tidak berpengaruh secara simultan, karena hasil uji f diperoleh nilai $\mathrm{f}_{\text {hitung }}$ sebesar 1,749 lebih besar dengan $\mathrm{f}_{\text {tabel }}$ sebesar 3,18, dan signifikasi sebesar 0,185 > 0,05 . Selanjutnya hasil uji determinasi sebesar 0,067 atau $6,7 \%$. Dengan demikian besarnya pengaruh variabel kualitas produk $\left(\mathrm{X}_{1}\right)$ dan Promosi $\left(\mathrm{X}_{2}\right)$ Terhadap Keputusan Nasabah (Y) di BMT Purwakarta Amanah Sejahtera sebesar $6,7 \%$. Sedangkan sisanya $93,3 \%$ ditentukan variabel lain yang perlu diteliti lebih lanjut karena keterbatasan penelitian ini.

\section{DAFTAR PUSTAKA}

Aini, Almusrijah, Habriyanto Habriyanto, and Darma Putra. 2021. "Pengaruh Pengetahuan, Kualitas Pelayanan, Dan Religiusitas Terhadap Keputusan Menjadi Anggota Baitul Maal Wa Tamwil Kota Jambi." UIN Sulthan Thaha Saifuddin Jambi.

Al-Arif, M Nur Rianto, and Rachmi N Hamidawati. 2011. Dasar-Dasar Ekonomi Islam. Surakarta: Era Adicitra Intermedia.

Andriyani, Meli, and Riski Ardianto. 2020. "Pengaruh Kualitas Layanan Dan Kualitas Produk Terhadap Kepuasan Nasabah Bank." EKOMABIS: Jurnal Ekonomi Manajemen Bisnis 1, no. 02: 133-40.

Anshori, Abdul Ghofur. 2018. Perbankan Syariah Di Indonesia. Yogyakarta: UGM PRESS.

Arikunto, Suharsimi. 2002. Prosedur Penelitian: Suatu Pendekatan Praktek. Cetakan Ke. Jakarta: PT. Rineka Cipta.
Fahriana, Ava Swastika. 2018. "Pengambilan Keputusan Secara Musyawarah Dalam Manajemen Pendidikan Islam: Kajian Tematik Al-Qur'an Dan Al-Hadist." AlHayat: Journal of Islamic Education 2, no. 1: 17-46.

Fakhrurradhi, Fakhrurradhi. 2021. "Analisis Faktor Yang Mempengaruhi Keputusan Nasabah Dalam Pengambilan Pembiayaan Rahn Di Pegadaian Syariah Cabang Pembantu Sigli." SINTESA: Jurnal Kajian Islam Dan Sosial Keagamaan 2, no. 1: 78-100.

Firmansyah, M. Anang. 2019. Perilaku Konsumen (Sikap Dan Pemasaran). Pasuruan: Penerbit Qiara Media.

Firmansyah, M Anang, and Didin Fatihudin. 2017. Globalisasi Pemasaran (Marketing Globalization). Yogyakarta: Deepublish.

Gayo, Ahyar Ari, and Ade Irawan Taufik. 2012. "Kedudukan Fatwa Dewan Syariah Nasional Majelis Ulama Indonesia Dalam Mendorong Perkembangan Bisnis Perbankan Syariah (Perspektif Hukum Perbankan Syariah)." Jurnal Rechts Vinding: Media Pembinaan Hukum Nasional 1, no. 2: 257-75.

Kamila, Mariam. 2021. Halo BMT: Optimization of BMT Functions through a Digital Data Collection Platform in Order to Reduce Inequality in the Country. Bogor: PT Penerbit IPB Press.

Kasmir. 2018. Pemasaran Bank. Jakarta: Prenada Media.

Kotler, Philip, and Gary Amstrong. 2012. Prinsip-Prinsip Pemasaran. 13th ed. Jakarta: Erlangga.

Kotler, Philip, and Gary Armstrong. 2008. Prinsip-Prinsip Pemasaran. Jakarta: Erlangga. 
Kotler, Philip, and K L Keller. 2009. Manajemen Pemasaran. Jakarta: Erlangga.

Kurniati, Devi Ayu, and Agung Guritno. 2019. "Strategic Charity Implementation In Indonesia's Rural Islamic Financial Institution." FINANSIA: Jurnal Akuntansi Dan Perbankan Syariah 2, no. 02: 265-74.

Morrisan. 2015. Periklanan Komunikasi Pemasaran Terpadu. Jakarta: Kencana.

Muchammadun, Muchammadun, Sri Hartini Rachmad, Dendi Handiyatmo, Ayesha Tantriana, Eka Rumanitha, and Zaenudin Amrulloh. 2021. "Peran Tokoh Agama Dalam Menangani Penyebaran Covid-19." Religious: Jurnal Studi Agama-Agama Dan Lintas Budaya 5, no. 1: 87-96.

Muhammad, D R. 2009. Model-Model Akad Pembiayaan Di Bank Syariah. Yogyakarta: Yogyakarta: UII Press.

Muttalib, Abdul. 2018. "Tingkat Pemahaman Guru Mata Pelajaran Pendidikan Agama Islam (PAI) Terhadap Produk Pembiayaan Pada Perbankan Syari'ah (Studi Pada Guru SMP Di Kota Mataram)." JUPE: Jurnal Pendidikan Mandala 3, no. 3: 54-63.

Rahfizah, Raudhatul Zahrah, Supaino Supaino, and Ahmad Kholil. 2020. "Pengaruh Kualitas Pelayanan Dan Kualitas Produk Tabungan IB Hasanah Terhadap Kepuasan Nasabah Pada PT Bank BNI Syariah Kantor Cabang Medan." Nisbah: Jurnal Perbankan Syariah 6, no. 1: 23-29.

Ratih, Hurriyati. 2005. Bauran Pemasaran Dan Loyalitas Konsumen. Bandung: Alfabeta.

Rini, Dyah Mustika, M Hufron, and Budi Wahono. 2020. "Pengaruh Kualitas
Pelayanan Dan Keunggulan Produk IB Hasanah Terhadap Kepuasan Nasabah Pada PT Bank BNI Syariah Malang." Jurnal Ilmiah Riset Manajemen 9, no. 22: 68-82.

Risal, Taufiq, and Austin Alexander. 2019. "Pengaruh Persepsi Bagi Hasil, Promosi Dan Kualitas Pelayanan Terhadap Minat Penggunaan Jasa Perbankan Syariah Tabungan Mudharabah Pada Mahasiswa Universitas Potensi Utama." Jurnal Samudra Ekonomika 3, no. 2: 118-30.

Romindo, Romindo, Muttaqin Muttaqin, Didin Hadi Saputra, Deddy Wahyudin Purba, M Iswahyudi, Astri Rumondang Banjarnahor, Aditya Halim Perdana Kusuma, Faried Effendy, Oris Krianto Sulaiman, and Janner Simarmata. 2019. E-Commerce: Implementasi, Strategi Dan Inovasinya. Medan: Yayasan Kita Menulis.

Rumondang, Astri, Acai Sudirman, Samsider Sitorus, Aditya Halim Perdana Kusuma, Melda Manuhutu, Andriasan Sudarso, Janner Simarmata, Dian Hasdiana, Tasnim Tasnim, and Nina Fapari Arif. 2020. Pemasaran Digital Dan Perilaku Konsumen. Medan: Yayasan Kita Menulis.

Salusu, Jonathan. 2015. Pengambilan Keputusan Stratejik. Jakarta: Gramedia Widiasarana Indonesia.

Sari, Anisa Kurnia Kurnia. 2013. "Pengaruh Citra Merek Dan Keluarga Terhadap Keputusan Pembelian Honda Beat." Jurnal Ilmu Manajemen (JIM) 1, no. 1.

Sari, Febrina. 2018. Metode Dalam Pengambilan Keputusan. Yogyakarta: Deepublish.

Setiadi, Nugroho J. 2019. Perilaku Konsumen: Perspektif Kontemporer Pada Motif, Tujuan, Dan Keinginan Konsumen. Edisi

EKSISBANK (Ekonomi Syariah dan Bisnis Perbankan), Volume 5, Nomor 2, Desember 2021 
Keti. Jakarta: Prenada Media.

Setiawan, Andriatma, and Arjuna Wiwaha. 2020. "Pengaruh Kualitas Produk Dan Promosi Terhadap Keputusan Pembelian Produk Tabungan Pada Pt. Bank Tabungan Negara (Persero), Tbk. Kantor Cabang Kelapa Gading Square." $E$ Journal Widya Ekonomika 2, no. 1: 3845.

Soemitra, Andri. 2008. Bank Dan Lembaga Keuangan Syariah. Jakarta: Kencana Prenada Media Group.

Subarkah, Andi, Heri Tohari, Muhammad Kafiyanto, Hedi Fajar Rahadian, and Saefudin. 2012. Himpunan Al-Qur'an Dan Terjemah New Cordova. Bandung: Syaamil Quran.

Sugiyono. 2006. Metode Penelitian Pendidikan : Pendekatan Kuantitatif Dan Kualitatif Dan R\&D. Bandung: Alfabeta. - 2015. Metode Penelitian Kuantitatif, Kualitatif Dan $R \& D$. Bandung: Alfabeta. -2017. Metode Penelitian Kuantitatif, Kualitatif, Dan R\&D. Bandung: Alfabeta.

Sugiyono, Drs. 2008. Metode Penelitian Bisnis. Bandung: Pusat Bahasa Depdiknas.

Sumarwan, Ujang. 2011. Perilaku Konsumen:

Teori Dan Penerapannya Dalam

Pemasaran. Bogor: Ghalia Indonesia.

Susanto, Herry, and Khoerul Umam. 2013. Manajemen Pemasaran Bank Syariah. Bandung: Pustaka Setia.

Tjiptono, Fandy. 2011. Prinsip-Prinsip Total Quality Service (TQS). Edisi 5. Yogyakarta: Andi Offset.

- 2020. Pemasaran Esensi \& Aplikasi. Yogyakarta: ANDI.

Wardana, Dwiyadi Surya. 2011. "Pengaruh Kepribadian Konsumen Pada Pilihan

EKSISBANK (Ekonomi Syariah dan Bisnis Perbankan), Volume 5, Nomor 2, Desember 2021 http://journal.sties-purwakarta.ac.id/index.php/EKSISBANK/ ISSN: 2654-8526 (Media Online) 2599-2708 (Media Cetak)
Merek Sebagai Konsep Diri Pada Kategori Produk." Jurnal Ilmiah Aset 13, no. 1: 21-35. 